\title{
Fault-controlled asymmetric landscapes and low-relief surfaces on Vestvågøya, Lofoten, North Norway: inherited Mesozoic rift-margin structures?
}

\author{
Steffen G. Bergh', Kristian H. Liland², Geoffrey D. Corner', Tormod Henningsen² \\ \& Petter A. Lundekvam \\ ${ }^{1}$ Department of Geosciences, University of Tromsø UiT-The Arctic University of Norway, 9037 Tromsø, Norway. \\ ${ }^{2}$ Equinor ASA, Harstad, Norway. \\ E-mail corresponding author (Steffen G. Bergh): steffen.bergh@uit.no
}

\begin{abstract}
The Lofoten Ridge is an integral basement horst of the hyperextended continental rift-margin off northern Norway. It is a key area for studying onshore-offshore rift-related faults, and for evaluating tectonic control on landscape development along the North Atlantic margin. This paper combines onshore geomorphological relief/aspect data and fault/fracture analysis with offshore bathymetric and seismic data, to demonstrate linkage of landscapes and Mesozoic rift-margin structures. At Leknes on Vestvågøya, an erosional remnant of a down-faulted Caledonian thrust nappe (Leknes Group) is preserved in a complex surface depression that extends across the entire Lofoten Ridge. This depression is bounded by opposing asymmetric mountains comprising fault-bounded steep scarps and gently dipping, partly incised lowrelief surfaces. Similar features and boundary faults of Palaeozoic-Mesozoic age are present on the offshore margin surrounding the Lofoten Ridge. The offshore margin is underlain by a crystalline, Permo-Triassic to Early Jurassic, peneplained basement surface that was successively truncated by normal faults, down-dropped and variably rotated into asymmetric fault blocks and basins in the Mesozoic, and the basins were subsequently filled by Late Jurassic to Early Cretaceous sedimentary strata. Comparison of the onshore asymmetric landscapes and offshore tectonic architecture supports the idea that disrupted low-relief surfaces, bounding steep scarps, ridges and depressions onshore the Lofoten Ridge, represent tectonic inheritance of a tilted basement-cover surface, rotated fault blocks and half-graben basins from Mesozoic rifting of the margin. In the Cenozoic, Mesozoic faults controlled the landscape by tilting and reactivated footwall uplift, followed by exhumation of the Mesozoic-Cenozoic cover sediments. Glacial erosion during the Pleistocene partly incised and modified these tectonic features, which nevertheless remain as distinct elements in the landscape.
\end{abstract}

Keywords: Lofoten Ridge, asymmetric landscapes, Leknes half-graben, low-relief palaeosurfaces, seismics, bathymetry data, Mesozoic rifting, Late Cenozoic exhumation

Received 20. December 2017 / Accepted 23. July 2018 / Published online 20. November 2018

\section{Introduction}

The rifted continental margin off Lofoten and Vesterålen (Fig. 1) formed during multiple phases of extension in the Palaeozoic and Mesozoic (Blystad et al., 1995; Brekke, 2000; Tsikalas et al., 2005, 2008). The resulting rift-margin architecture is that of a highly structurally controlled, Palaeozoic-Mesozoic, synrift sedimentary succession above Precambrian basement rocks, arranged in asymmetric basins and fault-bounded basement ridges, rotated fault blocks and tilted basement-cover surfaces (Bergh et al., 2007; Færseth, 2012; Hansen et al., 2012).

Precambrian basement rocks in coastal and onshore areas of Lofoten and Vesterålen, northern Norway (Fig. 1), form alpine landscapes having complex geometry, including peculiar asymmetric ridges and depressions

Bergh, S.G., Liland, K.H., Corner, G.D., Henningsen, T. \& Lundekvam, P.A. 2018: Fault-controlled asymmetric landscapes and low-relief surfaces on Vestvågøya, Lofoten, North Norway: inherited Mesozoic rift-margin structures? Norwegian Journal of Geology 98, 379-403.

https://dx.doi.org/10.17850/njg98-3-06. 


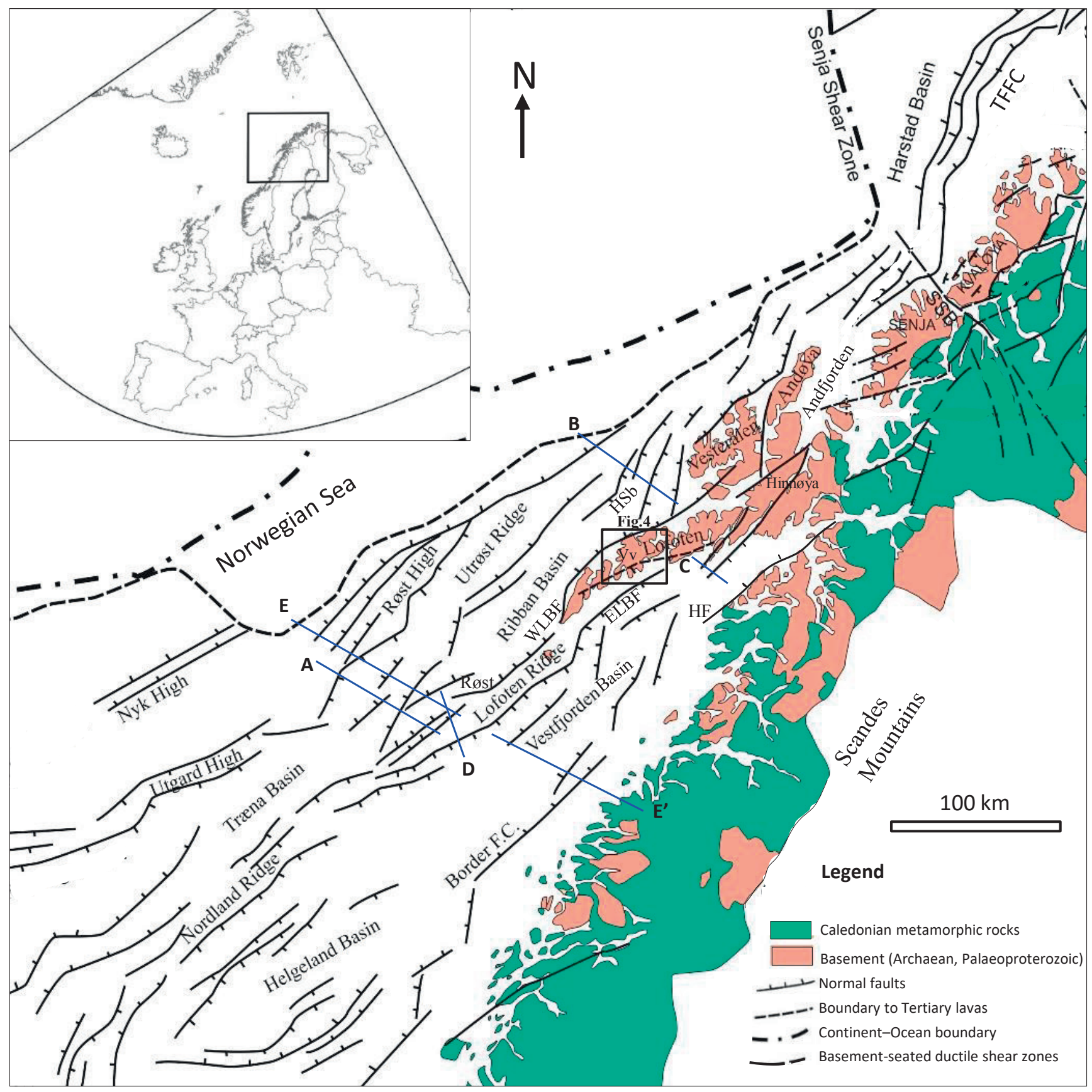

Figure 1. Onshore-offshore tectonic map of the Mid-Norwegian, Lofoten-Vesterålen, and SW Barents Sea margins (after Indrevor et al., 2013). Onshore geology is from Mosar et al., (2002). The frame outlines the study area of Vestvågøya, Lofoten islands (see Fig. 3). Lines A through E locate the studied seismic sections adjacent to the Lofoten Ridge. Abbreviations: ELBF - East Lofoten Border Fault, HF - Hamarøya Border fault, HSb - Havbåen Sub-basin, SSB - Senja Shear Belt, TFFC - Troms-Finnmark Fault Complex, Vv - Vestvågøya, VVFC - VestfjordVanna Fault Complex, WLBF - West Lofoten Border Fault.

comprising steep scarps and gently dipping (low-relief) geomorphological surfaces (Osmundsen et al., 2009, 2010; Schermer et al., 2016) (Fig. 2). The low-relief surfaces are smooth and dip at a gentle to moderate angle $\left(<30^{\circ}\right)$ from higher elevations at or near steep mountain summits and they commonly terminate in steep-sided valleys or steep coastal cliffs (dip $>30^{\circ}$, average $50-60^{\circ}$ ), in either case defining asymmetric landscapes. These landscape features are distinct despite some incision in places by younger forms, most notably glacial cirques in areas of highest relief and strandflat skerries and rock platforms along the coast (Møller \& Sollid, 1973; Corner, 2005a; Trulssen, 2008).

The present paper 1) analyses asymmetric landscapes near Leknes on the island of Vestvågøya in Lofoten (Fig. 2), where a major depression in the bedrock is surrounded by opposing asymmetric mountains, steep 
scarps and gently dipping, partly incised surfaces (Fig. 3 ), and 2) compares these landscape features with structures on the surrounding offshore rift margin. We apply onshore geomorphological relief, slope/ aspect data and fault/fracture analysis, combined with offshore bathymetric and seismic data, to explore these relationships. In this paper we argue for tectonic inheritance based on the resemblance of onshore asymmetric landscapes and low-relief surfaces to offshore Mesozoic rift-margin structures (e.g., Redfield et al., 2005; Osmundsen et al., 2009, 2010; Schermer et al., 2016). It also briefly discusses how asymmetric landscape features like those at Leknes relate to, but differ from, other palaeosurfaces discussed in the literature, such as the regional palaeic surface (Lidmar-Bergstrom et al., 2000, 2007; Bonow et al., 2006, 2007; Gabrielsen et al., 2010; Schermer et al., 2016; Fredin et al., 2017) and the strandflat (Olesen et al., 2013; Fredin et al., 2017). Our analysis also contributes to an understanding of the extent to which relict tectonic landscapes may be preserved onshore in rift-margin settings long after the termination of major active faulting (Lidmar-Bergstrom et al., 2000, 2007; Bonow et al., 2006, 2007; Osmundsen et al., 2009, 2010; Osmundsen \& Redfield, 2011; Schermer et al., 2016).

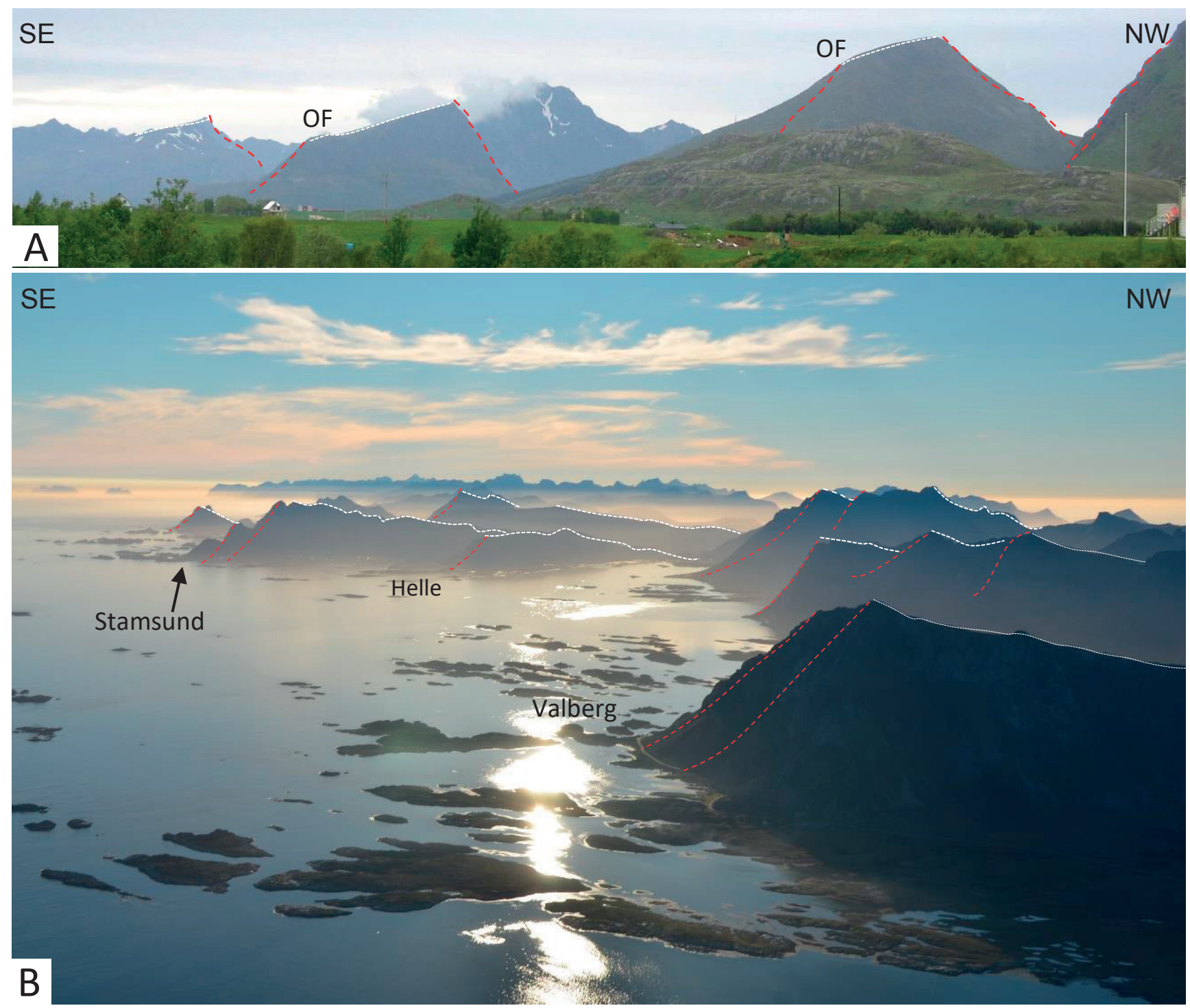

Figure 2. Examples of onshore asymmetric landscapes and ridgeline relief surfaces in Lofoten. (A) SE-dipping, low-relief surfaces (white stippled lines) bounded by steep scarps (red dashed lines), along the trace of the Offersøya fault (OF) in the valley of Leknes. (B) Oblique aerial photograph showing asymmetric landscapes along the southeastern part of Vestvågøya, outlined by steep coastal scarps (red dashed lines) dipping SE toward the Vestfjorden basin, and uniform NW-dipping low-relief $\left(5-30^{\circ}\right)$ summit and hillslope surfaces (white stippled lines). Note also horizontal flat top summit remnants in the background on the outermost Lofoten islands. See figure 3 for location of photos. 


\section{Geological setting and rift-margin architecture}

The Lofoten and Vesterålen islands consist of Neoarchaean gneisses intruded by a suite of Palaeoproterozoic magmatic rocks (Griffin et al., 1978; Corfu, 2004), overlain to the east by allochthonous nappes of the Scandinavian Caledonides (Fig. 1). Post-Caledonian extensional reactivation (collapse) of Caledonian thrusts in the Devonian, and brittle fault reactivation in the Permian, contributed to the formation of the Lofoten basement ridge as a metamorphic core complex (Steltenpohl et al., 2004, 2011). Today, the Lofoten Ridge is an integral basement horst of the hyperextended continental rift-margin off Mid Norway (Fig. 1) (Doré, 1991; Blystad et al., 1995; Løseth \& Tveten, 1996; Doré et al., 1997, 1999; Olesen et al., 1997, Bergh et al., 2007; Hansen et al., 2012; Peron-Pinvidic et al., 2013; Redfield \& Osmundsen, 2013). The rift-margin at Lofoten is underlain by extensional detachments and crustal domains having complex geometry and evolution history, and it is narrower than the Vøring margin farther south (Mosar et al., 2002; Osmundsen et al., 2002; PeronPinvidic et al., 2013). The post-Devonian rifting history started in the Permo-Triassic, was followed by major phases of extension in the Mid/Late Jurassic to Early Cretaceous, and culminated with oceanic crust and passive margin formation in Eocene time (Brekke et al., 2001; Tsikalas et al., 2001, 2005, 2008; Faleide et al., 2008).

The Lofoten basement horst is flanked by normal faults dipping NW and SE toward major basins in their offshore hangingwall, such as the Vestfjorden Basin on the landward side and the Ribban Basin, Træna Basin and Skomvær/ Havbåen Sub-basin on the seaward side of the Lofoten ridge (Fig. 1). These basins are filled by PalaeozoicMesozoic deposits and flanked by rotated fault blocks and a gently tilted basement-cover surface (Løseth \& Tveten, 1996; Olesen et al., 1997; Bergh et al., 2007; Hansen et al., 2012). The tilted basement-cover surface is offset by planar and listric normal faults creating numerous wedge-shaped sub-basins (Hansen et al., 2012). One such sub-basin, filled by Late Jurassic to Early Cretaceous strata, is preserved

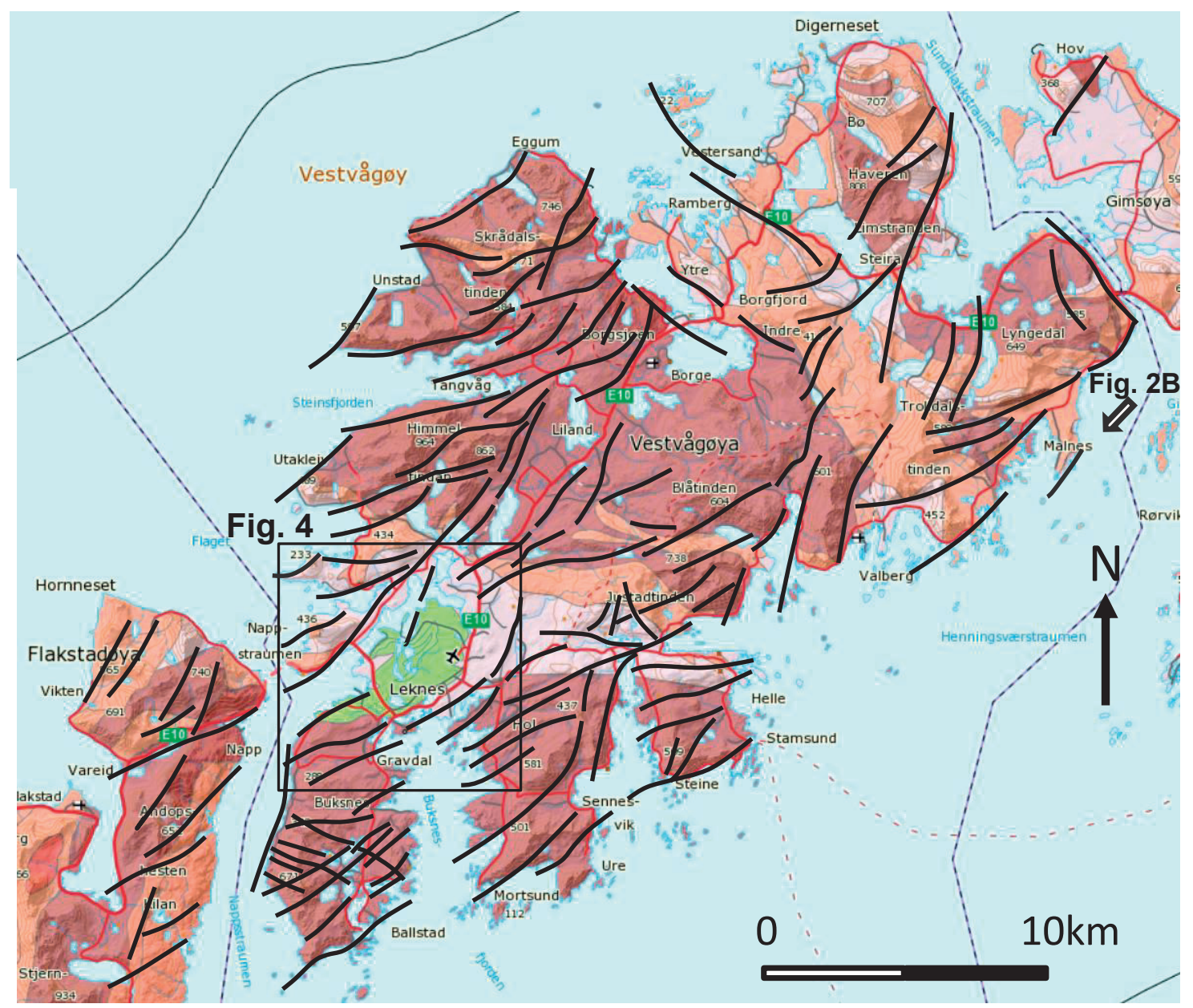

Figure 3. Bedrock geological map of Vestvågøya, Lofoten islands (www.ngu.no), showing Archaean gneisses (orange and pink) and mangerites (brown) of the Lofoten igneous suite basement, and Neoproterozoic metasupracrustal rocks of the Leknes Group (green), after Tull (1977), Tveten (1978) and Klein \& Steltenpohl (1999). Brittle faults and high-density fracture zones are shown as black lines, based on present and previous work (Bergh et al., 2007; Hansen et al., 2012). Arrow in the northeast shows view of figure 2B. For comparison of landscape features, see figures $2 B$ and 5 to 7. 
onshore Andøya (Fig. 1) (Dalland, 1981), and similar Mesozoic basins exist in Andfjorden (Forthun, 2014) and within fjords in Vesterålen (Davidsen et al., 2001; Fürsich \& Thomsen, 2005), suggesting that the entire islands were covered by Mesozoic sediments and later uplifted and exhumed (Osmundsen et al., 2010).

On the island of Vestvågøya (this study), a peculiar landscape depression exists in Precambrian mangerites and gneisses surrounding the Neoproterozoic Leknes Group meta-supracrustal rocks (Figs. $3 \& 4$ ), which are a preserved erosional remnant of a Caledonian thrust nappe (Tull, 1977; Klein, 1997; Klein \& Steltenpohl, 1999; Klein et al., 1999; Corfu, 2004, 2007). The Leknes Group is located in the central part of this depression (Figs. 3, $4 \& 5$ ) as gently NW-dipping thrust sheets tectonically emplaced over Neoarchaean gneisses and plutonic rocks (Tull, 1977; Klein \& Steltenpohl, 1999; Corfu, 2004). The
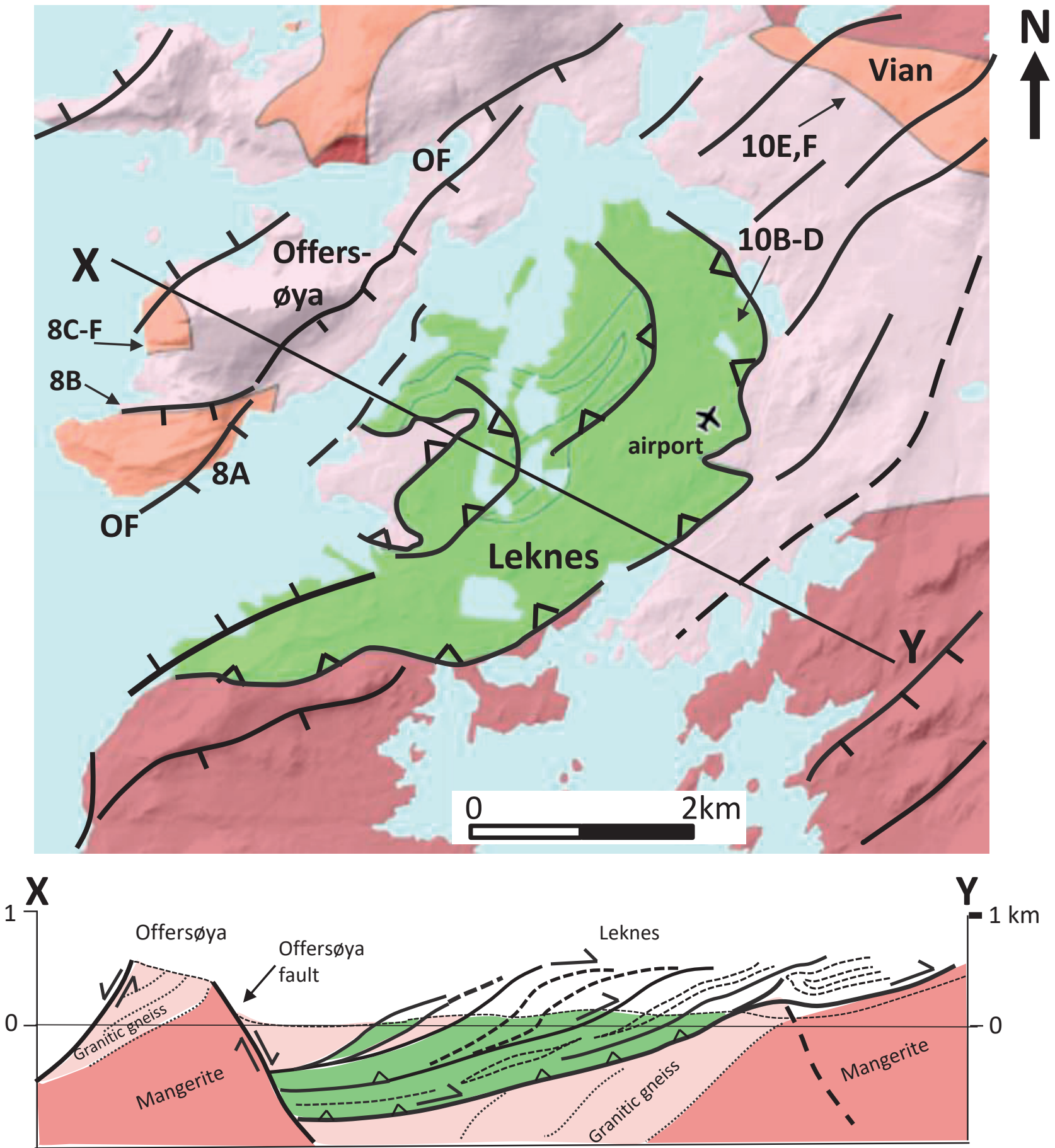

Figure 4. Detailed geological map and interpreted cross-section of the southern part of Vestvågøya near Leknes (www.ngu.no), showing the gently NW-dipping Leknes Group, its component thrust sheets, and its termination against the steep SE-dipping Offersøya normal fault northwest of Leknes (after Klein \& Steltenpohl, 1999). Note the moderately NW-dipping granitic gneiss fabric (black stippled lines in the crosssection) on Offersøya, subparallel to the intrusive contact of mangerites (Tull, 1977). Note locations of figure 8A-F at Offersøya. 

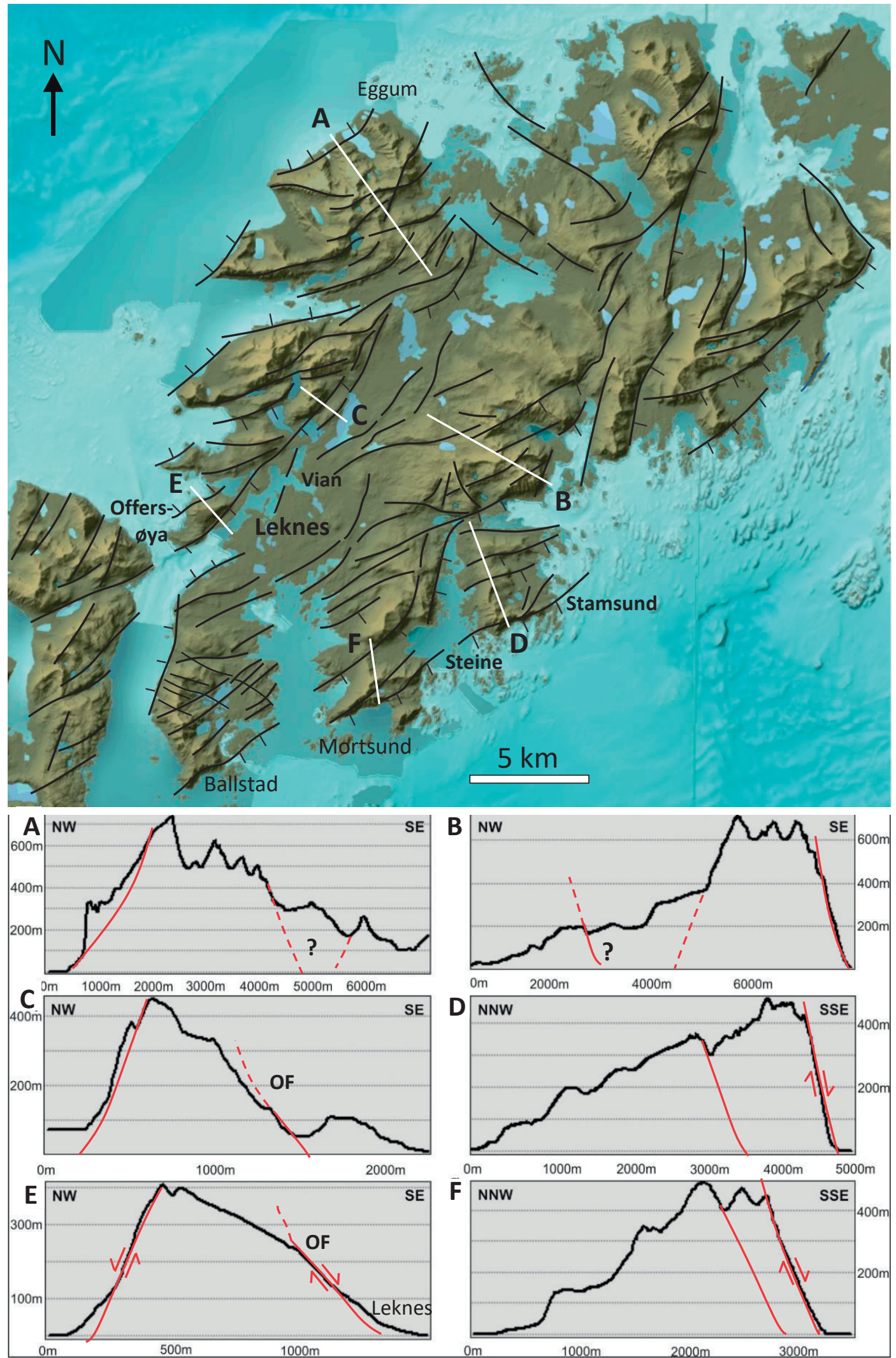

Figure 5. DEM relief map of Vestvågøya with interpreted brittle lineaments (black lines) and topographic profiles (A-F). The map illustrates contrasts in topography between steep coastal escarpments (dipping NW and SE, respectively) and low-relief surfaces dipping gently NW, and locally SE (on Offersøya), i.e., inwards towards the Leknes valley. Profile lines are drawn perpendicular to the main scarps. Red and dashed red lines (certain - uncertain) mark scarps interpreted as normal faults based on the position of lineaments following scarps and depressions coinciding with brittle faults and fracture zones (cf., Bergh et al., 2007). Note the location of the Offersøya fault (OF) in profiles C and E. 
presence of a major, SE-dipping, brittle normal fault on the northwest side of the depression, the Offersøya fault, led Klein \& Steltenpohl (1999) and Klein et al. (1999) to infer down-faulting of the Leknes Group along this fault (Fig. 4).

\section{Database and work flow}

We used DEM images accessed from www.Norgei3D.no to identify and trace tectonic lineaments, brittle faults and fracture sets on Vestvågøya (Fig. 5) for comparison with major landscape features observed in the field. ArcGIS (ArcMap 10.2) was used for the geomorphological study to produce hill-shade, aspect and slope-angle maps and relief maps locating scarps, depressions and low-relief surfaces (Fig. 6). We focused on steep escarpments that may correspond to normal faults, and on planar, smooth, continuous and discontinuous, gently dipping surfaces that truncate basement rock fabrics (i.e., foliation) and pre-date Quaternary glacial erosion and thus define relict palaeosurfaces (Schermer et al., 2016). We mapped such surfaces across the entire Vestvågøya (Fig. 6), particularly northwest and southeast of Leknes (Fig. 7), and tried to correlate surfaces at similar elevations. The derived dataset comprises two maps, 7504-1 and 7504-4 (Fig. 6), from the Norwegian Map Authority in USGS DEM-format, where each file covers a $50 \times 50 \mathrm{~km}$ area with a $10 \times 10 \mathrm{~m}$ resolution. The aspect map (Fig. 6A) and combinations of aspect and hillslope maps (Fig. $6 \mathrm{C}, \mathrm{D})$ were compiled using simple raster calculations in ArcMap, with selected $10-15^{\circ}$ of azimuth range, and slope intervals between 5 and $30^{\circ}$ (gently dipping/lowrelief surfaces) and $>30^{\circ}$ (steep surfaces). Aspect graphdata (Fig. 6B) were reprocessed in Excel.

Structural field studies were carried out in areas close to steep scarps and low-relief surfaces to test if faults correspond to such landscape features. For the offshore comparison studies we applied 50 x 50 m resolution hillshade bathymetry data from Mareano and reprocessed offshore seismic data (Statoil 1980-90), and a few nondepth-converted sections tied to drillcores in Nordland VII (6824/04-U-1 \& U-2) (Smelror et al., 2001).

\section{Results}

\section{Geomorphology and asymmetric landscapes of Vestvågøya}

The topography of Vestvågøya is characterised by asymmetric mountain ridges and peaks with elevations up to 700 m.a.s.l., located on either side of a broad valley or depression centred at Leknes (Fig. 3). The map and topographic profiles (Figs. 3 \& 5), in combination with aspect data (Fig. 6A, B) and topographic hillslope maps (Fig. 6C, D), show two well-defined, NE-SW trending, opposed mountain ridges on the northwestern and southeastern sides of the island at Leknes. In addition, planar and smooth, gently dipping surfaces are inclined mostly inwards against the NE-SW-trending, elongated, almost flat valley/depression at Leknes. Farther northeast on Vestvågøya, the valley at Leknes broadens and is underlain by more oblique and variable, NNE-SSW- and NW-SE-trending scarps, smaller valleys and ridges (Figs. 5 \& 6).

The asymmetric depression at Leknes is delineated by trends in the spatial distribution of mountains on either side of the valley (Fig. 5). Azimuth values indicate a dominance of steep/moderate $\left(>30^{\circ}\right)$ scarps having dip directions of c. $130^{\circ} \pm 10^{\circ}$ (SE) and $315^{\circ} \pm 10^{\circ}$ (NW) (Fig. 6A), seen as peaks in the histogram (Fig. 6B). The hillslope data further show that steep surfaces, sporadically distributed, correspond to coastal scarps and glacial cirques in the northwest and southeast (Fig. $6 \mathrm{C})$, whereas low-relief surfaces dip gently $\left(<30^{\circ}\right) \mathrm{NW}$ (in central Vestvågøya) and partly SE (near Offersøya) into the Leknes valley (cf., Fig. 6D). The central and northeastern part of Vestvågøya show, in addition, linear scarps and mountain ridges trending NNE-SSW and NW-SE (Figs. 5 \& 6), which are more variable than the NE-SW-trending depression at Leknes.

The mountain region northwest of Leknes terminates against coastal escarpments that dip steeply NW and extend from sea level to summits up to $700 \mathrm{~m}$ high (Fig. 7A). These major scarps are located only a few kilometres southeast of the NW-dipping, extensional West Lofoten Border Fault (Fig. 1), and thus may be an onshore, footwall expression of this major horst-boundary fault (see discussion). At Offersøya, a smooth, near-continuous hillslope dips gently SE into the Leknes valley (Figs. 4, 5, \& 7A, B). This low-relief surface appears at an elevation of between 220 and 400 m.a.s.l. It truncates the bedrock gneiss foliation (Fig. 4, cross-section) and is itself cut by a steep SE-dipping scarp (c. $45^{\circ}$ ) that terminates at the valley at Leknes (Figs. 5E \& 7A, B). This scarp can be traced in hillsides along strike to the northeast, overlaps with the presumed Offersøya fault (Klein, 1997; Klein \& Steltenpohl, 1999), and has a similar trend to other presumed, brittle fault zones in the northern part of Lofoten Ridge (cf., Wilson et al., 2006; Bergh et al., 2007; Hansen et al., 2012) (see below).

Southeast of Leknes, similar asymmetric mountains and hillslopes exist, with the highest peaks (400-600 m.a.s.l.) located on coastal escarpments that dip SE toward Vestfjorden (Figs. 5, $6 \& 7 \mathrm{C}, \mathrm{D}$ ). From these peaks the surface relief descends gently $\left(5-30^{\circ}\right) \mathrm{NW}$ until it reaches the floor of the Leknes valley. The low-relief surfaces are remarkably planar and smooth (Fig. 2B) and can be connected not only along the ridgelines, but also between 


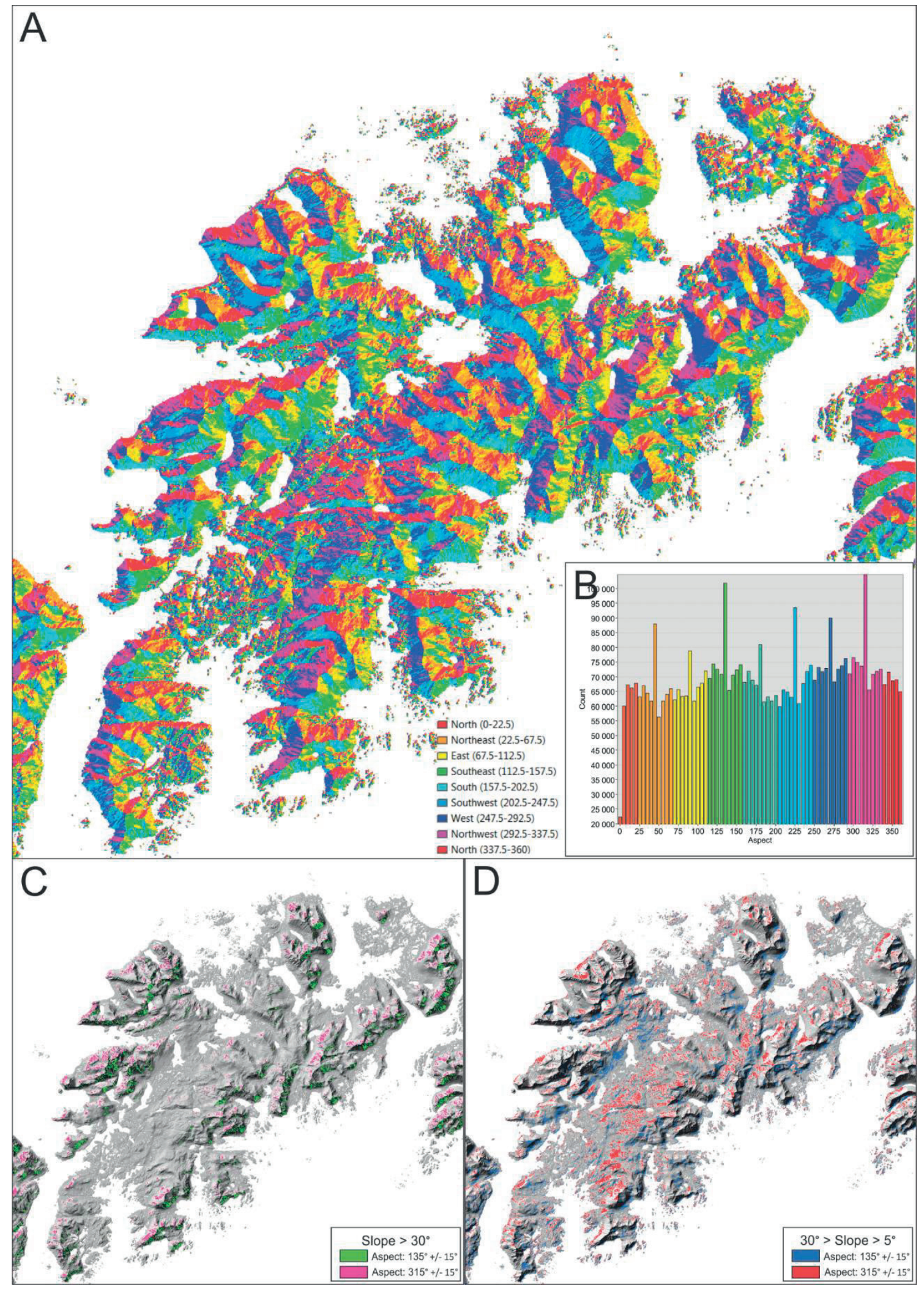

Figure 6. (A) Aspect/azimuth map of Vestvågøya with aspect colour codes (in B) given in degrees relative to north. (B) Histogram of aspect dip direction. Narrow aspect traces on the map indicate steeply dipping surfaces; broad traces indicate gently dipping surfaces. Note peaks around $115-155^{\circ}$ (green) and 300-330 (pink) in the histogram, marking a predominance of surface dip toward SE and NW, respectively. Data modified after Hansen (2009). (C) Combined aspect and hill-slope (relief) map of Vestvågøya showing the location of surfaces with slope $>30^{\circ}$. Note that steep NW- and SE-dipping hill-slopes (pink and green, respectively) appear predominantly in high-relief areas where they represent a variety of fault-controlled scarps, sea cliffs and incised glacial landforms. (D) Aspect and hill-slope map showing location of gently dipping surfaces $\left(5^{\circ}<\right.$ slope $\left.<30^{\circ}\right)$. Note that such low-slope surfaces dip NW in south-central parts of Vestvågøya and SE near Offersøya, i.e., inwards against the Leknes valley. 

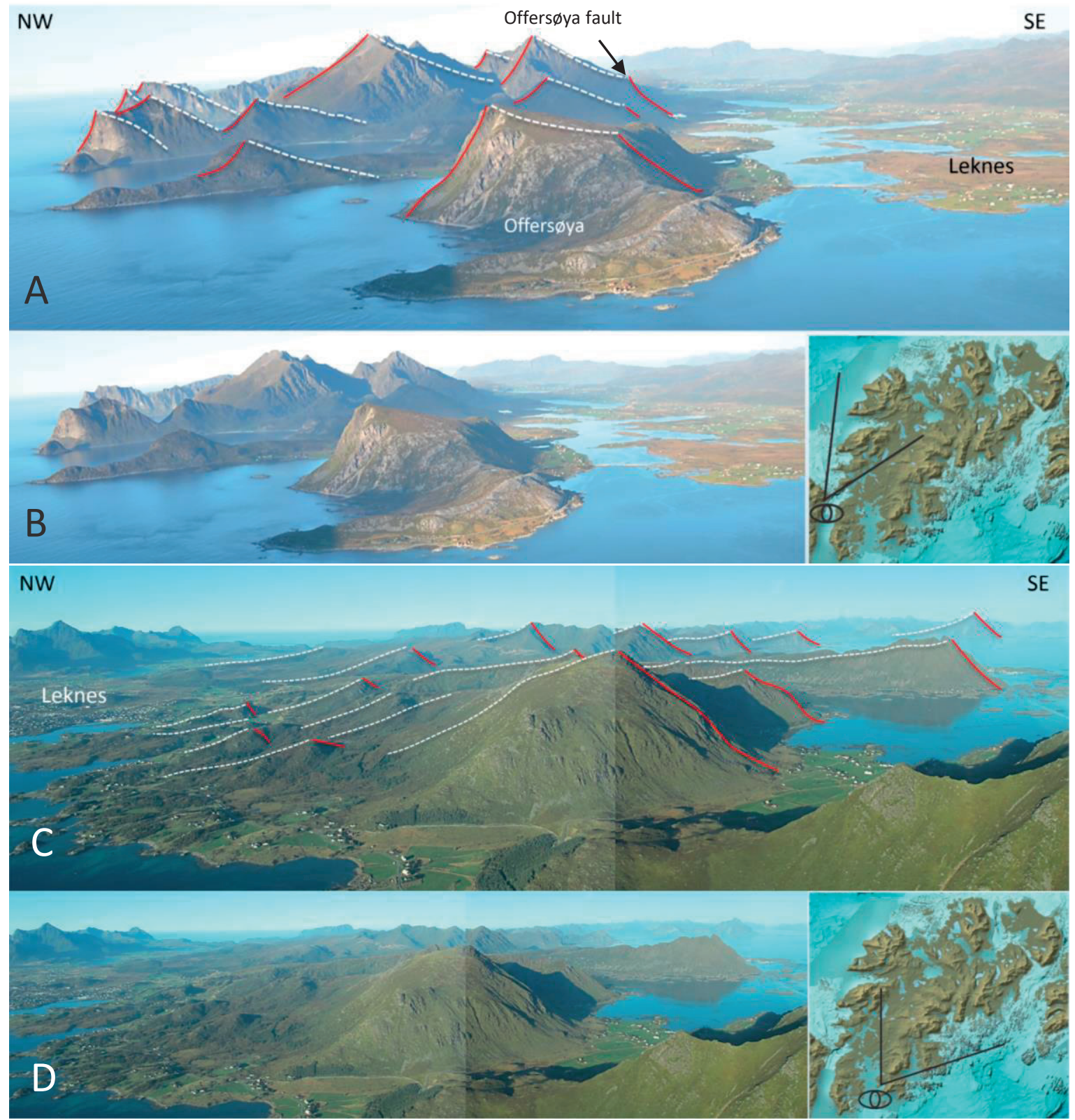

Figure 7. $(A, B)$ View of the mountains northwest of Leknes, with (A) and without (B) interpretation. Note the asymmetric mountains/ridges with steep, NW-dipping escarpments (red lines) and gently SE-dipping surfaces (dashed white lines). The low-relief surface on the island of Offersøya in the foreground is planar, smooth and vegetation-covered, and bounded by an additional, steep, SE-dipping scarp facing toward the Leknes valley, along the Offersøya fault (Klein \& Steltenpohl, 1999). (C, D) Compiled interpreted and uninterpreted photos of southeastern parts of Vestvågøya, showing similar but opposed asymmetric landscapes as in Fig. 7A, B, comprising coastal scarps dipping SE, and uniform low-relief surfaces dipping gently NW into the Leknes valley. All photographs were taken from an aeroplane. Index maps show areas of view between black lines.

individual mountain ridges and chains of summits and ridges over distances of up to several kilometres both along and across strike. Locally, however, the surfaces are broken and truncated by small, narrow valleys and scarps dipping SE in the opposite direction (Fig. 7C), as depicted by the geomorphological data (Figs. $5 \& 6$ ).

In summary, the mountains on either side of the Leknes valley/depression reveal a striking, opposed asymmetry, with a planar, low-relief surface dipping gently $\left(5-30^{\circ}\right)$ NW toward Leknes, and scarps dipping steeply SE at Offersøy and on the southeastern side of Vestvågøya, and steeply NW on the northwestern side of the island (Fig. 7). Subsidiary WNW, N and NE dip directions for both gentle and steeply dipping surfaces (Fig. 6), in combination, give a rather complex, rhombic-shaped depression in map view. 


\section{Escarpments and brittle faults}

To investigate possible relationships between escarpments surrounding the Leknes valley and potential brittle faults on the Lofoten horst, structural field studies were carried out in bedrock exposures adjacent to major escarpments at: i) Offersøya (Fig. 8), ii) between Stamsund and Steine in the southeastern part of Vestvågøya (Fig. 9), and iii) inside the valley of Leknes underlain by the Caledonian Leknes Group metasupracrustal rocks (Fig. 10).

\section{Offersøya}

This small peninsula northwest of Leknes has a very characteristic shape in profile, delimited by two steep scarps dipping NW and SE and a more gently SE-dipping surface in between (Figs. 7A \& 8A, B). Bedrock consists of homogenous mangerite, and granitic gneiss with a weak foliation dipping moderately NNW. All the observed geomorphic surfaces truncate this gneiss foliation. The escarpment that dips c. $45^{\circ} \mathrm{SE}$ toward the Leknes valley is interpreted to be the site of the Offersøya fault (Klein \& Steltenpohl, 1999). There is no exposed bedrock along the fault trace, but a nearby road-cut in foliated granitic gneiss (locality 8A in Fig. 4, arrow in Fig. 8A) displays a high frequency of interacting NNE-SSW and NE-SW shear fracture sets (Fig. 8H, I). Shore outcrops and steep cliffs on the northwestern side of the peninsula expose numerous fracture damage zones and minor fault-core zones (Fig. $8 \mathrm{~B}-\mathrm{F}$ ). The dominant fracture sets dip $>70^{\circ}$ ESE and NW, respectively (Fig. 8I) and are well outlined in beach and cliff sections (Fig. 8B), defining rhombicshaped map geometries (Fig. 8C). Locally, NW- and ESEdipping faults with decimetre-thick zones of cataclasite offset the gentle, NW-dipping foliation down to the SE and ESE (Fig. 8D-F). In the road-cut near the Offersøya fault, the NNE-SSW-trending fault set merges into the NE-SW-trending fractures, and both sets contain secondary mineral growth (hematite, chlorite, quartz). Striations on fault surfaces in the road-cut point to oblique-normal and subordinate dextral strike-slip components of movement (Fig. 8I), suggestive of NW-SE oriented transtension (cf., Bergh et al., 2007; Eig, 2008). These data, overall, support the presence of at least two overlapping brittle normal fault cores and a high density of fracture sets in damage zones parallel to the inferred Offersøya fault strand, located in its nearby footwall (cf. Fig. 4).

\section{Stamsund - Steine}

The villages of Stamsund and Steine are located in the southeastern part of Vestvågøya, on a small peninsula along the foot of a NE-SW-trending and steep SE-dipping coastal escarpment (Fig. 9A, B). This scarp terminates upwards in a very regular, low-relief summit surface of a gently (c. $\left.15^{\circ}\right) \mathrm{NW}$-dipping ridge extending c. $4 \mathrm{~km}$ inwards, before it is cut by a second, steep mountain scarp (Fig. 2B), thus defining part of a repeated, asymmetric mountain ridge system opposing that of
Offersøya. The host rocks at Stamsund are mangerites without visible fabric. The main SE-dipping coastal scarp is parallel to a set of high-frequency planar faults and fractures in damage zones that dip steeply $\left(>50^{\circ}\right) \mathrm{SE}$ and NW (Fig. 9C, D, F), suggesting two sets of conjugate shear fractures (Fig. 9F). Subsidiary, steep, NNE-SSW-trending fractures also exist in the area. Most of the mapped fractures display a planar geometry in map view and cross-section, and individual surfaces commonly contain hematite and chlorite. Slickenside fibres on SE-dipping fault surfaces in mangerites yield dominant normal dipslip, down-to-the-SE and/or NW movement, locally with a weak oblique-sinistral component (Fig. 9F), supporting the presence of normal faults along the escarpment(s) between Stamsund and Steine.

\section{Leknes valley}

The Leknes valley in central Vestvågøya (Figs. 3, 4, 5 \& $10 \mathrm{~A})$ is mostly covered by glacial debris, but there are bedrock exposures in some easily accessible quarries. One quarry, c. 500 m north of Leknes airport (Fig. 4), exposes gently NW-dipping, foliated mica schists and bedded quartzites of the Leknes Group (Fig. 10B, C, D), whereas underlying basement mangerites and granitic gneisses are exposed in another quarry at Vian c. $3 \mathrm{~km}$ farther north along the main road (Fig. 10E, F). In both quarries, consistent NE-SW-trending fractures dominate and show variable but mostly opposite steep dips to the NW and SE, defining interacting, parallel and acute, crosscutting (conjugate) zones both in map view and crosssection (Fig. 10C). Subordinate sets striking NNE-SSW and ENE-WSW are also present. Typically, oppositely $\mathrm{NW}$ - and SE-dipping conjugate faults in damage zones that truncate gently NW-dipping foliation surfaces, together define graben and/or half-graben structures and contain both planar and listric fault surfaces (Fig. 10B, C, D). Notably, high-density shear fractures are abundant in fault damage zones surrounding fault cores, while joint swarms characterise areas farther outside and along the subordinate fracture trends, thus providing supporting evidence for major fault zones in the valley.

NW- and SE-dipping minor faults crop out as distinct zones with brown-coloured cataclasite and fault gouge (Fig. 10E, F). Associated fault surfaces are coated with hematite and/or epidote and display slickenside fibres. Orientation and slickenside data for measured faults at Vian (Fig. 10G, H, I) reveal dominant dip-slip, normal to normal-oblique motion, i.e. alternating down-to-the-NW and SE, with a slight component of sinistral strike-slip displacement (Fig. 10I). Normal-oblique movement senses are obtained also for subordinate NNE-SSSWand ENE-WSW-striking faults in the Leknes valley.

In summary, NE-SW-striking, steeply NW- and SE-dipping brittle normal faults and shear fractures, and subordinate NNE-SSW fracture sets, largely overlap with scarps and ridges and thus mimic the geometry of the large-scale, asymmetric and rhombic- 

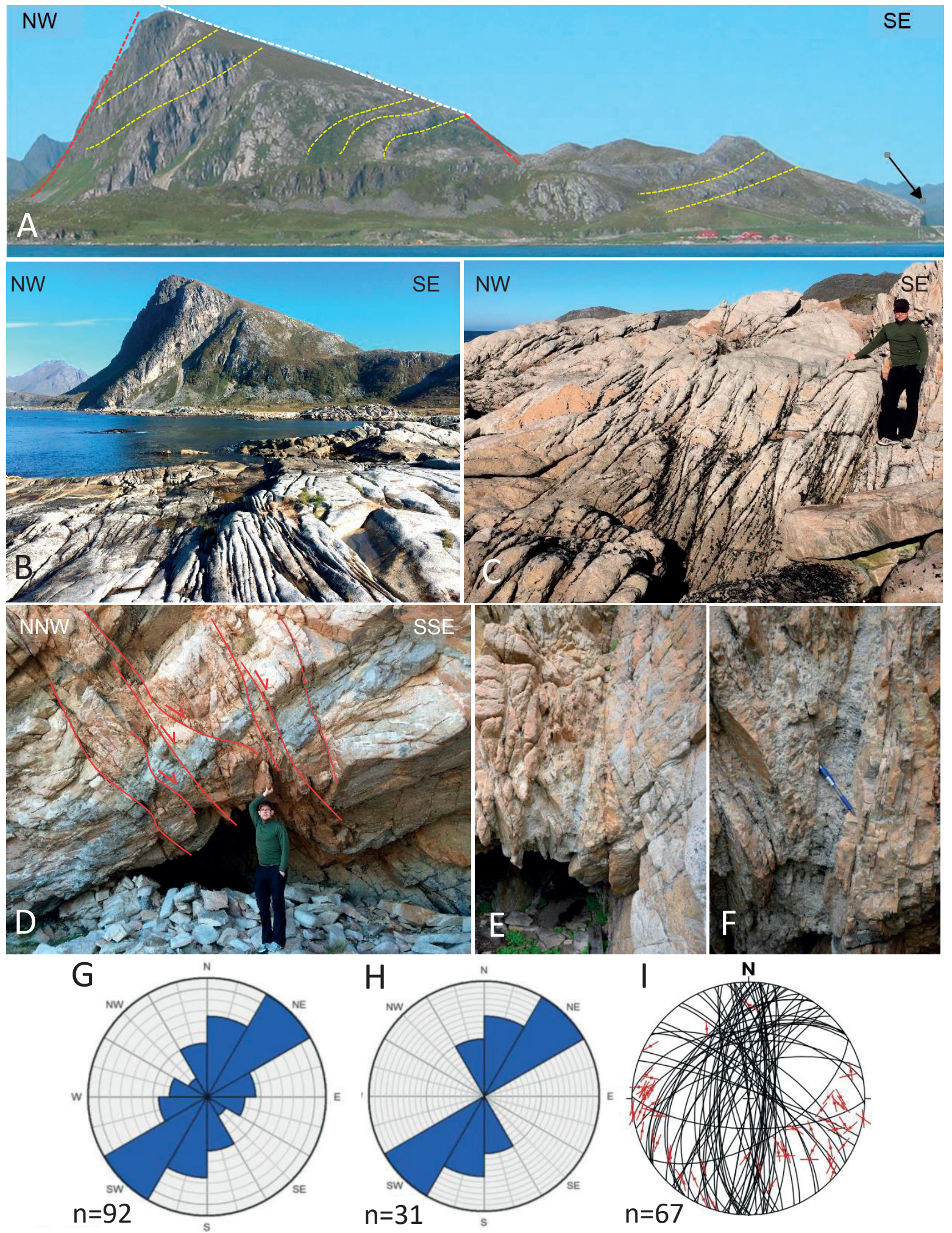

Figure 8. Investigated localities and bedrock structures at Offersøya (see figure 4 for locations). (A) Overview of the asymmetric-shaped Offersøya northwest of Leknes, showing a steep NW-dipping coastal scarp (dashed red line), a SE-dipping low-relief surface truncating steeper gneiss foliation (dashed yellow lines), and a scarp with SE dip toward Leknes valley (red line, right). Black arrow locates road-cut along the Offersøya fault, $8 \mathrm{~A}$ in figure 4. (B) Northwestern shoreline at Offersøya exposing mangerite and high-density fractures with steep SE dips. (C) Sets of interacting steeply NW-and WNW-dipping fractures. (D) Example of ESE-dipping faults (subparallel to the Offersøya fault) that offset the NW-dipping granitic gneiss foliation by normal, down-to-the-ESE motion (half-arrows). (E, F) Close-up of conjugate faults (ESE and NW dips) with cataclasite developed in decimetre-thick zones. $(G)$ Rose diagram plot of fault and fracture trends in the same shoreline localities. (H) Rose diagram of faultsfractures in a road-cut near the Offersøya fault (arrow in figure 8A). (I) Equal-area, lower hemisphere stereogram of small-scale normal and normal-oblique faults (great circles) in the same road-cut as in figure $8 \mathrm{H}$, with slickenside striations shown as slip-linear plots, i.e., pole of fault in the centre of the red arrow line representing the movement (M-) plane (Aleksandrowski, 1985). 

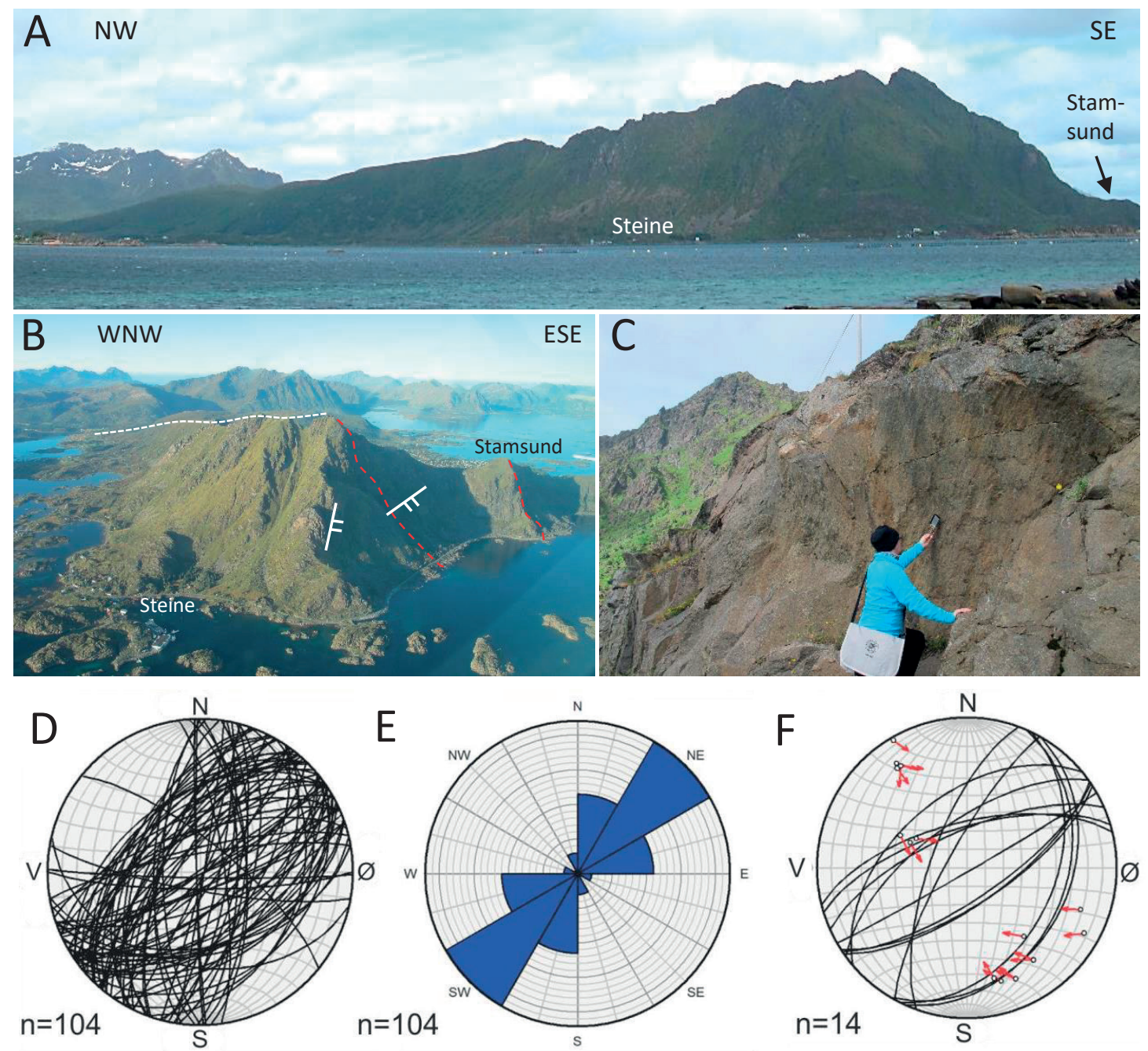

Figure 9. (A) Asymmetric mountain on the peninsula between Stamsund and Steine, southeast Vestvågøya. Note the steep, coastal, SE-dipping escarpment, and a very gentle, NW-dipping, low-relief surface. (B) Aerial view of the peninsula in A, showing a more irregular shape of the coastal scarp with steep NNE-SSW- and NE-SW- trending scarps (faults). (C) Small-scale fault surface with slickensides in a bay between Stamsund and Steine, revealing down-to-the-SE normal movement. (D) Equal-area, lower-hemisphere stereogram of small-scale faults and fractures (great girdles) along the main scarp of the peninsula. (E) Rose diagram of the same dataset as in D, showing fault-fracture trends. (F) Slip-linear stereogram showing conjugate SE- and NW-dipping normal fault sets from the same area.

shaped depression at Leknes on Vestvågøya, suggesting a close correspondence of fault-related landscapes (see discussion).

Fault patterns from bathymetry data on the shallow shelf and strandflat

Hill-shade bathymetric data from the shallow shelf/ strandflat surrounding Vestvågøya were used to compare and correlate onshore landscape/scarps and offshore fault strands (Fig. 11). The eastern and western boundary faults of the Lofoten ridge (ELBF, WLBF) define major sea-floor escarpments and mark the transition to the Ribban and Vestfjorden basins, respectively. The main bathymetric scarp in Vestfjorden (Fig. 11C) displays a depth change of the sea floor by up to $300 \mathrm{~m}$ and coincides with the seismic interpretations of the boundary fault there (Rokoengen \& Sættem, 1983). Thick glacial sediments with pronounced linear, glacial features cover the sea floor southeast of the scarp (Ottesen et al., $2005 a, b)$, while only thin glacial sediments cover the bedrock on the seaward side of the Lofoten ridge (Fig. 11C).

The strandflat on the southern side of Vestvågøya (Fig. $11 \mathrm{C}$ ) is a wide coastal rim of rock platforms and skerries lying between c. $50 \mathrm{~m}$ above and below present sea level (Corner, 2005a). It cuts across all rock structure and is bounded landwards by linear, steeply SE-dipping scarps. Since the adjacent onshore bedrock is largely homogenous mangerite, the recorded bathymetric lineaments are interpreted to reflect brittle fracture networks (cf. Bergh et al., 2007). Close to the coastal cliffs, a prominent NNE-SSW-trending lineament set displays a high frequency of narrow, rectilinear 

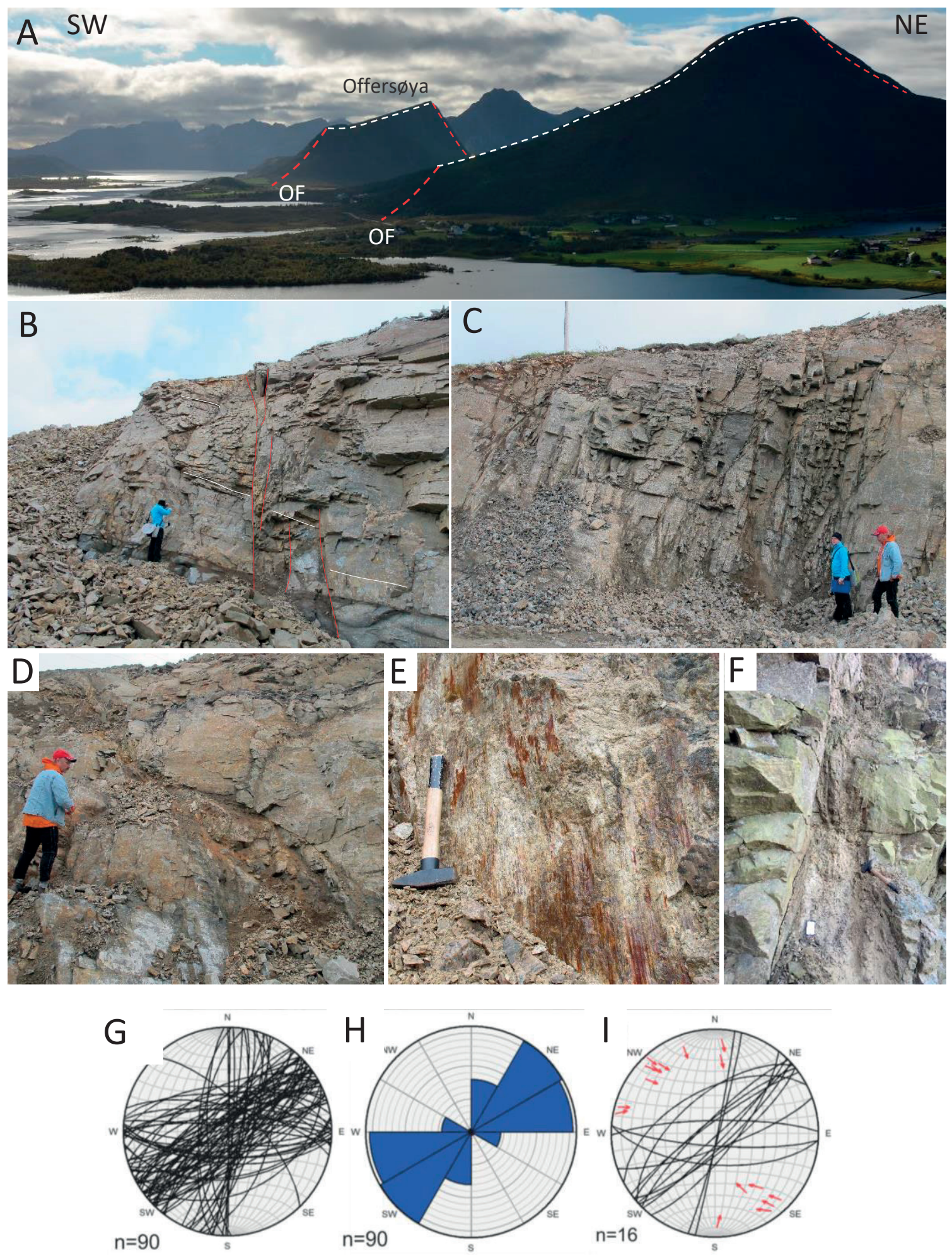

Figure 10. Investigated localities and bedrock structures in the Leknes valley (see figure 4 for locations). (A) Leknes valley and surrounding asymmetric ridges viewed along the trace of the Offersøya fault. $(B, C)$ Outcrop of Leknes Group metapsammitic gneiss in quarry north of Leknes airport, near the Offersøya fault. The gneiss foliation dips gently NE (white lines) and is cut by high-density, cataclastic fault zones (red lines) with steep dips alternating to the NW and SE. Note the steep, conjugate faults defining small-scale grabens. (D) Detailed image of a cataclastic fault zone (same locality as in B, C), with listric ramp-flat geometry. (E) NW-dipping, normal fault surface in mangerite, coated with hematite and quartz in a quarry at Vian, $2 \mathrm{~km}$ north of the Leknes Group. (F) Steep NE-SW-trending fault zone with slickenside fibres in mangerite at the Vian quarry, with metre-thick fault core consisting of mixed cataclasite and epidote-rich fault gouge. Compass for scale. (G) Equal-area, lower-hemisphere stereogram of small-scale brittle faults (great circles) and fractures from the quarry at Vian. (H) Rose diagram of the same dataset as in $G$, showing fault-fracture trends. (I) Slip-linear stereogram showing conjugate SE- and NW-dipping normal faults and subsidiary oblique-normal faults with steep $E$ and $S$ dips, from the Vian quarry. 


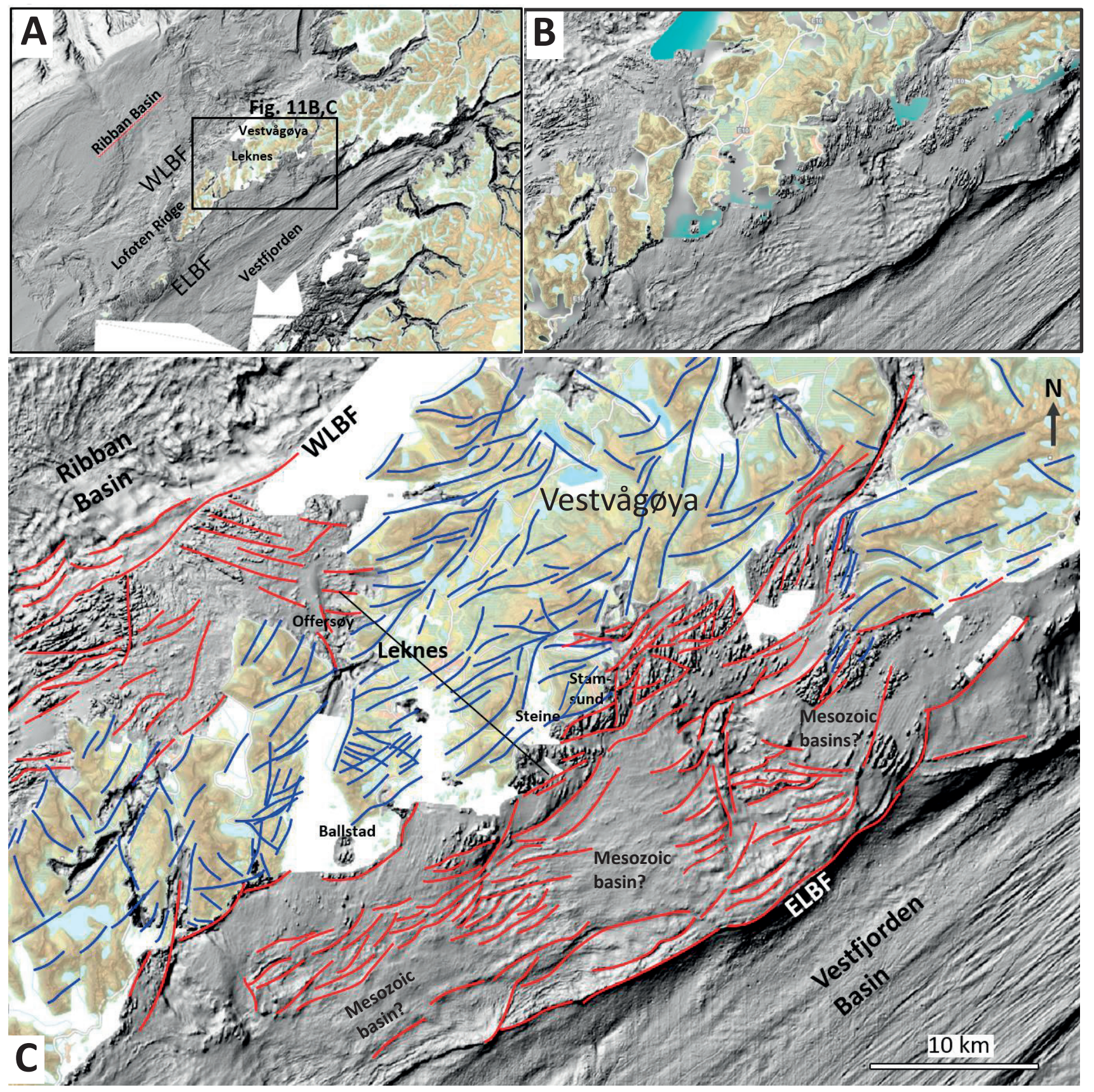

Figure 11. Bathymetry data (www.mareano.no) from the offshore areas surrounding the Lofoten Ridge at Vestvågøya. (A) Regional hillshade (relief) bathymetry map of the entire Lofoten Ridge, surrounding offshore Ribban and Vestfjorden basin areas and mainland Nordland. (B) Bathymetry map of the shallow strandflat/shelf areas on either side of the Lofoten Ridge at Vestvågøya, with interpretations of tectonic lineament (fault-fracture) trends on the strandflat (red lines), combined with interpreted onshore lineaments (blue lines) (Fig. 3, this work). Note the similarity of onshore and offshore lineament patterns, pronounced scarps along the ELBF and WLBF, and the presence of potential Mesozoic sedimentary basins on the shelf southeast of Vestvågøya (smooth grey areas without lineaments).

depressions and ridges that locally deflect or merge into a NE-SW-trending set (Fig. 11C). The NE-SW set is less frequent, but more regular and located in depressions having an undulating geometry subparallel to the coast. The NE-SW and NNE-SSW bathymetry lineaments can also be traced and linked directly to mapped brittle fractures (fault strands) onshore, e.g. south and east of Stamsund, Steine and Mortsund (Fig. 11C), where the interaction of the two prevailing lineament sets (faults) suggests a similar offshore fault-fracture pattern as that mapped onshore. In addition, the bathymetry data reveal subsidiary, N-S- to NNW-SSE-trending lineaments oriented oblique to the island and which appear to divide the Lofoten ridge at Vestvågøya into lateral domains.

Offshore rift-margin patterns from seismic data Seismic data from the shelf surrounding Lofoten have been used by previous authors to correlate and link 
onshore and offshore faults (e.g., Wilson et al., 2006; Bergh et al., 2007, 2008; Eig, 2008; Hansen, 2009; Færseth, 2012; Hansen et al., 2012). For this paper, we studied both published and unpublished seismic sections to compare and link onshore landscape features and offshore Mesozoic rift-margin structures.

NW-SE seismic sections on either side of the Lofoten Ridge show the margin-scale architecture of the ridge and surrounding basins and basin-bounding faults (cf. Bergh et al., 2007). The top-basement reflection is generally irregular and marks a distinct transition from diffuse-reflection, crystalline, basement rocks to wellstratified reflections in the overlying synrift PermoJurassic through Early/Mid Cretaceous sedimentary intervals (Fig. 12A, B). This surface is truncated by normal faults and tilted, forming asymmetric, rotated fault blocks and intervening half-grabens. The halfgraben sediments comprise wedge-shaped, thickened prisms against growth faults of Jurassic to Early Cretaceous age, and are overlain and masked by Late Cretaceous to Early Cenozoic postrift sediments (cf. Tsikalas et al., 2005; Bergh et al., 2007; Eig, 2008; Færseth, 2012; Hansen et al., 2012). The Cenozoic and Quaternary strata are mostly horizontal.

In the Ribban Basin northwest of the Lofoten Ridge (Fig. 12A), Early Cretaceous synrift, wedge-shaped strata overlie southeastward-ward tilted basement fault blocks, while pre-Cretaceous (Permo-Jurassic) strata in the Træna Basin resting against the Røst High are tilted northwestwards (Fig. 12A), forming part of a major rollover structure (cf., Bergh et al., 2007; Hansen et al., 2012; Henstra \& Rotevatn, 2014; Henstra et al., 2016). The Havbåen Sub-basin farther northeast, bounded by the Lofoten Ridge and the Utrøst Ridge, consists of several, oppositely dipping (synthetic-antithetic) faults bounding variously rotated fault blocks (Fig. 12B). The fault blocks are consistently asymmetric, with a steep planar fault that becomes listric down-section, and a gently dipping basement-cover surface marked in the seismic sections by a strong set of Early Cretaceous reflections. The basement surface dips gently and mostly inward toward the main fault of the wedge basins, producing a system of repeated smaller sub-basins (Hansen et al., 2012; Henstra \& Rotevatn, 2014; Henstra et al. 2016). The resulting ridge-basin geometry, imaged by the top-basement surface, is typical of extensional, imbricate, half-graben systems with rotated fault-block architectures (Løseth \& Tveten, 1996; Olesen et al., 1997; Bergh et al., 2007; Hansen et al., 2012).

In the Vestfjorden Basin southeast of Lofoten Ridge, however, seismic data show a more uniform topbasement configuration in near-shore areas, marked by the strandflat (Fig. 12C). Crystalline mangeritic basement rocks define diffuse patterns, but also some overlying, gently inclined, stratified reflections down to about 1.5s TWT, that could represent either strong sea- bottom multiples or sedimentary strata. Shelf-internal disturbances, truncations and offset of the top-basement reflection are observed and may represent small horsts and sediment-filled graben structures on the shallow shelf (Fig. 12C). Notably, the strandflat cuts through all these features.

Farther south, a seismic section across the entire Lofoten Ridge at Røst (Fig. 13) reveals more details of the ridgeinternal structures and its transition to the offshore basins. Diffuse reflections indicate crystalline basement rocks close to the seabed. Near the Lofoten Ridge margins, well-stratified reflections are offset down to c. 5.0s TWT in the Vestfjorden and Ribban basins (Fig. 13), where Permo-Jurassic, Early Cretaceous and Mid/ Late Cretaceous strata are interpreted to lap onto the Lofoten Ridge (Haraldsvik, 2015; Lundekvam, 2015). The ELBF defines a system of SE-dipping planar normal faults that become listric down-section and flatten into a level below the surrounding basins. The ELBF shows variable normal offset between 0.8 and $2 \mathrm{~s}$ TWT, with a total throw of c. 4s TWT. Similar, planar normal faults (WLBF) appear on the northwestern side of the Lofoten Ridge, dipping NW toward the Ribban Basin, where sedimentary strata are at a much higher level (2.6s TWT) and faults reveal much less throw (2.4s TWT). Internally, the crystalline basement of the Lofoten Ridge shows diffuse reflections truncated by faults bounding smaller zones with stratified reflections (Fig. 13). We interpret the stratified features as small basins filled with PalaeozoicMesozoic strata bounded by horsts with planar normal faults that dip alternately NW and SE and showing maximum down-throw of the top-basement reflector of between 0.1 and 0.7s TWT. A planar, domino-style fault and asymmetric half-graben geometry is realistic compared to the much larger off-ridge boundary faults and asymmetric fault blocks there.

\section{Discussion}

The islands of Lofoten are part of a coastal range (horst) on the North-Atlantic passive continental margin characterised by alpine high-relief topography typified by sharp ridges, peaks, cirques and U-shaped valleys (Møller \& Sollid, 1973; Corner, 2005b; Trulssen, 2008). These landscapes extend northeastward to Troms and Finnmark (Fig. 1) and are generally considered to be the product of glacial erosion, even though the underlying influence of tectonic structure may be prominent on elevated and eroded passive margins (Bonow et al., 2006, 2007; Burke \& Gunnell, 2008; Osmundsen et al., 2010; Schermer et al., 2016). Below, we argue that the Leknes landscape on Vestvågøya was controlled by Mesozoic rift-margin faulting, that low-relief surfaces may be inherited relict geomorphic surfaces, likely corresponding to the offshore basement-cover surface in 


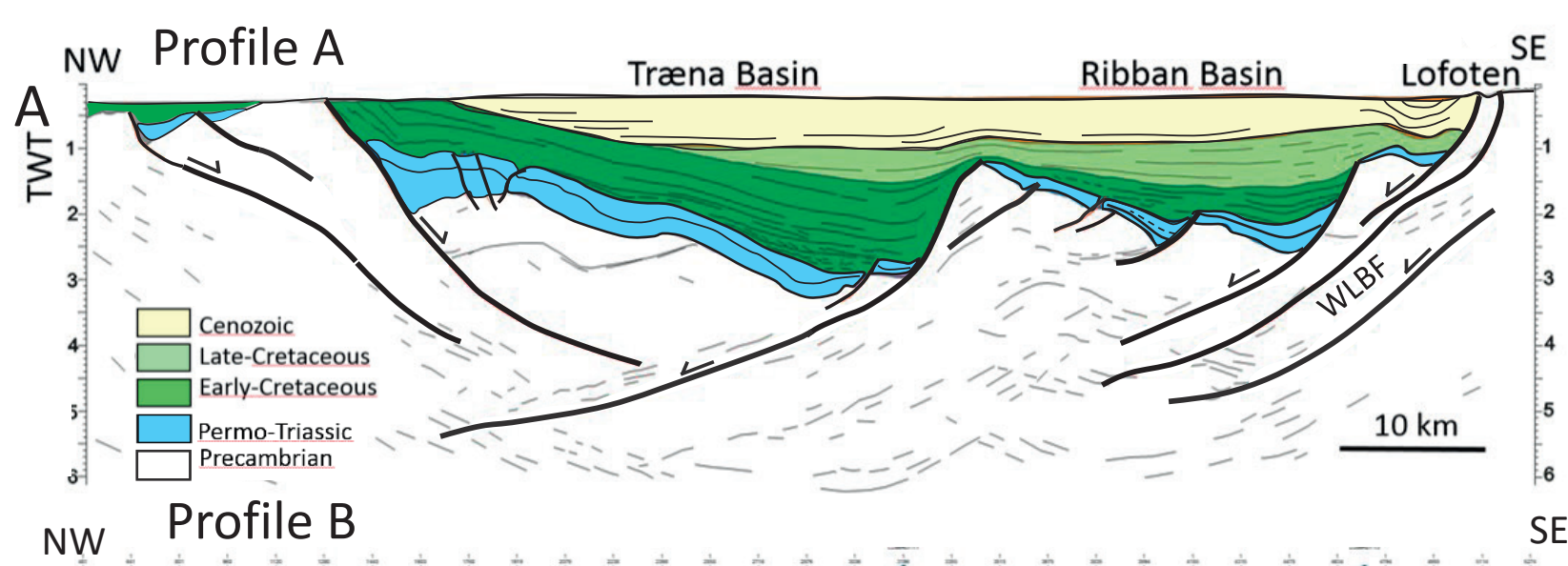

B
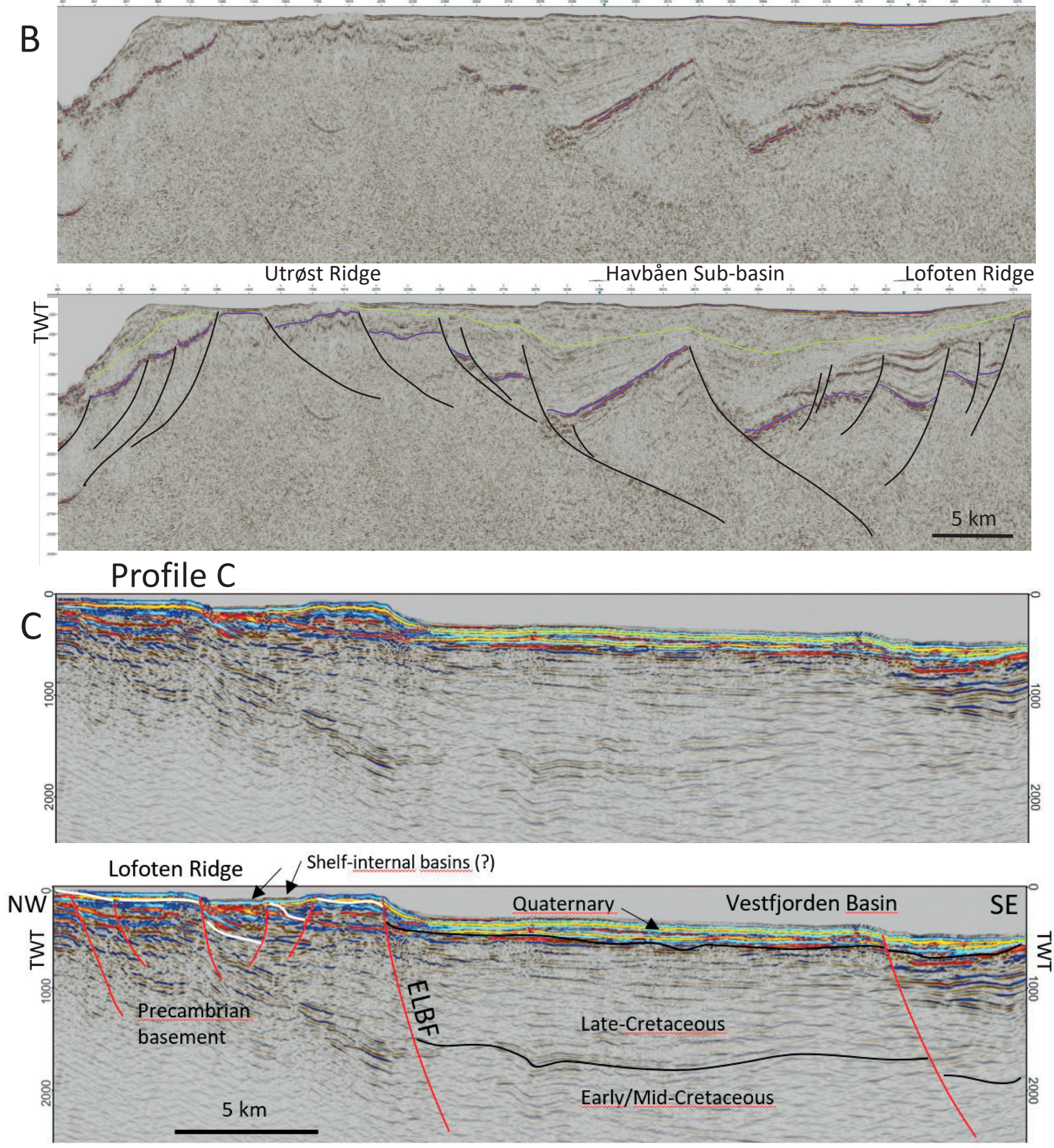
Figure 12. (A) Interpreted seismic section (line A in Fig. 1) of offshore areas northwest of the Lofoten Ridge, including the Ribban Basin and the northern part of the Trona Basin (Statoil, N692R000301), from the margin near Røst, after Hansen et al. (2012). (B) Uninterpreted (above) and interpreted (below) seismic section (line $B$ in Fig. 1) (Statoil, LO87R07-38) through the Havbåen Sub-basin between the Lofoten Ridge and the Røst High (see Fig. 1). A variably tilted top-basement surface lies below a very strong Early Cretaceous reflection (purple line). Note half-grabens between rotated fault blocks filled with Cretaceous strata (synrift), and overlain by Late Cretaceous and Cenozoic (above yellow line) post-rift strata (cf. Hansen et al., 2012). (C) Uninterpreted and interpreted seismic section (line C in Fig. 1) (Statoil, B-218-73R14), showing shelfinternal grabens, the main scarp in sea-floor reflections adjacent to the shelf edge marking the site of the ELBF, and a smaller scarp farther offshore in the Vestfjorden Basin (right). The interpreted sedimentary strata in the Vestfjorden basin are from Blystad et al. (1995), Bergh et al. (2007) and Hansen et al. (2012). passive-margin architecture, and that these relict surfaces have been exposed through exhumation from the overlying Mesozoic-Cenozoic sedimentary cover and preserved despite locally intense glacial erosion during the Pleistocene.

\section{Relationship of the Leknes landscape to rift-margin fault patterns}

On Vestvågøya, the landscape locally is alpine but expresses a clear asymmetric ridge-valley type relief, affected by glacial erosion. For example, the valley depression at Leknes is surrounded by opposed asymmetric ridges with steeply dipping (average 50-60 escarpments and gently $\left(5-30^{\circ}\right)$ inward-dipping lowrelief surfaces (Fig. 7). These observations, combined with relief map, aspect and hill-slope maps, demonstrate a half-graben geometry for the depression, in which the

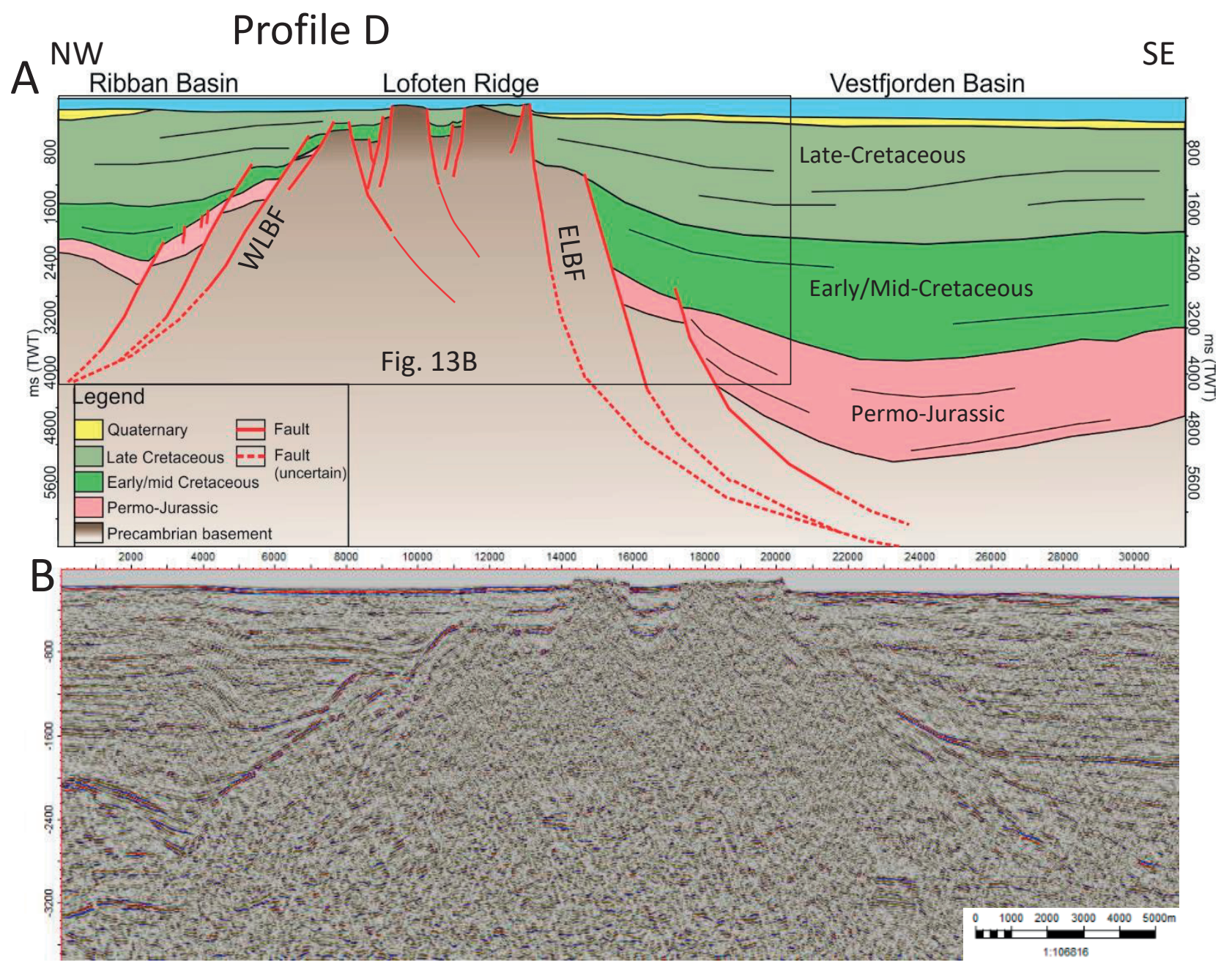

Figure 13. (A) Interpreted seismic section (line D in Fig. 1) traversing the entire Lofoten Ridge (Statoil, GMNR-94-108L) south of the island of Røst. Note the Lofoten Ridge, its internal architecture and border faults (ELBF and WLFB) against the Vestfjorden and Ribban basins to the southeast and northwest filled with Permo-Jurassic, Early/Mid-Cretaceous and Late Cretaceous sedimentary units. (B) Uninterpreted part of section in A, showing the internal architecture of the Lofoten Ridge, including well-stratified reflections and diffuse basement reflections. The top-basement surface is displaced and down-dropped by possible normal faults that in combination define small, tilted (?) half-graben basins filled with sedimentary strata. 
delimiting Offersøya fault and coast-parallel steep scarps dip SE and smooth low-relief surfaces dip gently toward the valley at Leknes. Field data confirm that steep $>30^{\circ}$ linear escarpments bounding the asymmetric ridges coincide with brittle normal faults and high-frequency fracture zones. Observed faults strike dominantly NE-SW and NNE-SSW and dip both NW and SE. Normal and normal-oblique movement of these faults is confirmed by slickensides on fault surfaces and cataclastic fault rocks in basement rocks at Offersøya, Stamsund-Steine and Vian, and by brittle faults in the Caledonian Leknes Group. These onshore faults are largely parallel to the Lofoten horst-boundary normal faults (Fig. 1).

The full 3D geometry of the half-graben at Leknes, however, is uncertain. If the Leknes Group basement rocks are tilted northwestwards towards the Offersøya fault, as seems to be the case (Klein \& Steltenpohl, 1999), this fault would define the northern boundary of the half-graben. On the southeast side, no opposite-dipping faults are exposed, but the half-graben boundary there is marked by gently dipping (low-relief) ridge-summit surfaces (Fig. 7C). The Leknes depression can therefore be interpreted as a northwestward-tilted half-graben against the Offersøya fault (Fig. 4, cross-section). This geometry, however, does not explain the inward (SE) dipping lowrelief surface northwest of Leknes at Offersøya (Figs. 5E \& 7A), which is itself truncated by the steep, Offersøya fault (see discussion below). A pinch-out of the Leknes half-graben c. $25 \mathrm{~km}$ farther northeast is inferred, where oblique, NNE-SSW-trending faults merge to produce a rhombic-shaped geometry and there is a switch to more complex, NW-SE-trending, geomorphological elements (Fig. 3). The half-graben likely also dies out westward in outermost Lofoten, where aspect/hill-slope and fault data reveal varied and dominantly NW-SE-trending, geomorphological and structural features, and a much more rugged alpine landscape (cf. Trulssen, 2008; Eig \& Bergh, 2011) than on Vestvågøya.

The steep escarpments and brittle faults that define the Leknes half-graben on Vestvågøya correlate with regional-scale, NNE-SSW and NE-SW-riking, normal and oblique-normal faults of presumed PalaeozoicMesozoic age in western Lofoten, mapped by Gabrielsen et al. (2002), Wilson et al. (2006), Bergh et al. (2007, 2008), Hansen (2009), and Hansen et al. (2012). The former set (NNE-SSW) strikes parallel to most fjords and sounds in a right-stepping and relay geometry, whereas the second set (NE-SW) is parallel to the main trend of the Lofoten Ridge. In Vesterålen, similar-oriented faults are found at Sortlandsundet, where they bound a half-graben basin in the fjord (Davidsen et al., 2001; Osmundsen et al., 2010), and on Andøya where Late Jurassic to Early Cretaceous sedimentary rocks crop out (Dalland, 1981; Fürsich \& Thomsen, 2005; Forthun, 2014). Notably, aspect/azimuth and dip-maps of faults both on the Lofoten Ridge and adjacent offshore margin (Hansen, 2009; Hansen et al., 2011, 2012), correspond in attitude with surface scarps observed by us on Vestvågøya, suggesting a genetic relationship.

In all these examples, a clear coincidence of NE-SWand NNE-SSW-trending, steep geomorphic surfaces (scarps) and brittle fault-fracture sets exists producing, in combination, a map pattern consisting of a complex, rhombic-shaped, half-graben or ridge-basin system (Figs. $5 \& 7$ ). The brittle normal fault patterns thus greatly influence the topography on Vestvågøya by delineating steep mountains, escarpments, coastal cliffs, aligned fjords, glacial valleys and cirques.

\section{Relationship of low-relief surfaces to rift-margin faulting}

The low-relief surfaces in the Leknes half-graben are part of asymmetric landscape ridges recognised by their gently $\left(<30^{\circ}\right)$ dipping attitude, commonly inward toward major steep escarpments/faults, defining both smooth slopes and planar surfaces connecting summit ridges (Figs. 2B \& 5). These relationships suggest generally weak glacial erosion of tilted, tectonically-controlled palaeosurfaces adjacent to major normal faults (cf., Osmundsen et al., 2010). Since such tilted surfaces in the study area consistently truncate basement contacts and gneiss foliation, and are preserved in isolation at the tops of ridges and peaks, they are considered to be reliable palaeosurfaces that were originally flat-lying and presumably could be either Mesozoic-Cenozoic or Quaternary in age (cf. Lidmar-Bergström, 1999, 2000, 2007; Etzelmüller et al., 2007; Schermer et al., 2016). The origin and age of such surfaces, however, remain uncertain (Nielsen et al., 2009, 2010; Osmundsen et al., 2010; Steer et al., 2012).

Our favoured explanation is that the low-relief, tilted surfaces represent the remnants of an extensive, peneplained surface generated by erosion along the North Norwegian margin during Late Triassic-Early/ Late Jurassic times (Reusch, 1901; Riis, 1992, 1996; Riis \& Fjeldskaar, 1992; Smelror et al., 2007; Hansen et al., 2012; Fredin et al., 2017). This surface was faulted and tilted during the main rifting events in Late Jurassic-Early Cretaceous times, then covered with sediments during the Mesozoic-Early Cenozoic (cf., Fig. 12A, B), and uplifted and exhumed during the Cenozoic, including during the Pleistocene glaciations. Temporal uplift and fault reactivation in the area is confirmed by apatite fission track age-jumps across major faults in Lofoten and Vesterålen, indicating that kilometre-scale fault reactivation and footwall uplift took place onshore after c. 90-70 Ma (Redfield et al., 2005; Hendriks et al., 2007, 2010; Osmundsen et al., 2010; Davids et al., 2013).

A Mesozoic age and rift-related origin for the tilted, lowrelief surfaces on Vestvågøya is supported by the abrupt termination of these surfaces against opposed, steeply- 
dipping scarps/normal faults of the complex Leknes halfgraben system (Fig. 5), suggesting they were all part of a uniform palaeosurface tilted and rotated by Mesozoic rift/extensional tectonic processes (Schermer et al., 2016). However, surfaces with more variable dip directions also exist on Vestvågøya, and may have been tilted and/or back-tilted during several faulting events (Bergh et al., 2008; Schermer et al., 2016). For example, the inward (SE) dipping low-relief surface at Offersøya northwest of Leknes may have been back-tilted first, against an older, NW- or WNW-dipping normal fault, now masked in the Leknes valley, and then later truncated by the Offersøya fault. This model is favoured by previous work advocating an early stage of NNE-SSW-trending faulting (cf., Bergh et al., 2007) followed by main-stage extension with coast/ridge-parallel, NE-SW-trending major faults. Interaction of these two fault sets may then explain the overall asymmetric and rhombic-shaped geometry of the Leknes half-graben (Fig. 5).

\section{Relationship of the Leknes half-graben to offshore rift-margin architecture}

The offshore seismic data from the Lofoten margin show that the top-crystalline basement surface is offset by normal faults that delimit mega-scale rotated fault blocks and asymmetric half-graben basins filled by Permo-Jurassic and Late Jurassic to Early Cretaceous sedimentary strata, e.g. as in the Ribban Basin and Havbåen Sub-basin (Fig. 12A, B). The Mesozoic fault blocks and basins were located along border faults that became listric at depth (Bergh et al., 2007; Hansen et al., 2012), producing rotation (roll-overs) in the hangingwall and associated, footwall uplift. Our work demonstrates that similar, but smaller-scale, down-dropped and tilted basement surfaces exist in asymmetric half-grabens in fjords in Vesterålen and even internally on the Lofoten Ridge itself (Figs. 11, 12C \& 13). Furthermore, tilted basement-cover surfaces and overlying Mesozoic deposits, defining half-grabens, are described onshore Andøya (Dalland, 1981), in Andfjorden (Forthun, 2014), Sortlandssundet (Davidsen et al., 2001; Osmundsen et al., 2010), and along the southern Nordland coast (Johannessen \& Nøttvedt, 2008; Bøe et al., 2010).

Although Mesozoic sedimentary strata are not exposed in the Leknes half-graben, such deposits may have been present prior to Cenozoic exhumation (see below), as inferred from the down-dropped Caledonian thrust sheet in its centre (Klein, 1997; Klein and Steltenpohl, 1999). The rhombic-shaped, asymmetric half-graben geometry, steep boundary normal fault dipping SE (Offersøya fault) and low-relief palaeosurfaces dipping NW (Figs. 5, 6 \& 7), all support an analogy of the Leknes half-graben with the offshore Mesozoic half-graben basins (see Fig. 14). In this context, the low-relief surfaces at Leknes resemble the attitude of the gently tilted basement-cover surface in the Træna and Ribban basins (Fig. 12A, B), bounding fault blocks of Late Jurassic age, except that the dip of master normal faults in these basins is northwestward (Fig. 14). This geometrical resemblance suggests that the low-relief surfaces in the Leknes half-graben mimic the peneplained Triassic-Jurassic erosion surface. This surface was down-dropped to the SE and accompanied by footwall uplift and hangingwall rotation to the NW against steeply SE-dipping, listric Mesozoic normal faults (Hansen et al., 2012). By comparison, the highest asymmetric mountains in Vesterålen (Fig. 1) appear in footwall blocks adjacent to the steeply NW-dipping basin-bounding Sortlandsundet normal fault, while a major, low-relief surface exists in the hangingwall, dipping SE and being overlain by Jurassic-Early Cretaceous sedimentary rocks (Davidsen et al., 2001; Osmundsen et al., 2010).

During the Cenozoic, the North-Atlantic rift margin underwent $>5 \mathrm{~km}$ of uplift and erosion, and deposition of more than $4 \mathrm{~km}$ of sediments in adjacent offshore areas (Brekke, 2000; Brekke et al., 2001; Hendriks, 2003). Such uplift, caused perhaps by ridge-push, local mantle pluming and/or crustal flexuring (cf. Schermer et al., 2016), may have induced reactivation of Mesozoic faults and thus contributed to the preservation of inherited Mesozoic features on the Lofoten Ridge. For example, on the hangingwall sides of the normal faults, downfaulted Mesozoic basement surfaces were likely preserved and exhumed during later uplift and erosion, as in the hangingwall of the Sortlandssundet fault (Osmundsen et al., 2010). On the footwall side, however, low-relief surfaces may have different ages due to deeper bedrock erosion there, while Permo-Jurassic surfaces were preserved on the hangingwall side. Alternatively, the low-relief footwall surfaces are younger and formed by renewed footwall uplift and fault reactivation. Thus, fault reactivation during the Cenozoic probably had a subsidiary effect on tilting of palaeosurfaces and development of local drainage systems in an inherited Mesozoic landscape (Redfield et al., 2005; Osmundsen et al., 2010).

The fact that Lofoten horst-bounding normal faults are linked to basement-seated listric detachments (Tsikalas et al., 2005; Bergh et al., 2007; Hansen et al., 2012), typical for a necking domain of hyperextended riftmargins (Peron-Pinvidic et al., 2013), could explain why relict Mesozoic landscapes are preserved onshore in coastal areas of passive-margin settings (Lofoten) long after the termination of major active faulting (LidmarBergström et al., 2000, 2007; Bonow et al., 2006, 2007; Osmundsen et al., 2009, 2010; Osmundsen \& Redfield, 2011; Schermer et al., 2016). Necking domains develop where the margin is thinnest, and where uplift and tilting due to fault reactivation is likely to occur (Peron-Pinvidic et al., 2013; Redfield \& Osmundsen, 2013). This accords well with crustal taper models (Osmundsen \& Redfield, 2011), which purport that rift-margin topography may be rejuvenated or maintained well beyond the initial rift 
phases (Weissel \& Karner, 1989; Peron-Pinvidic et al., 2013).

\section{Palaeosurface exhumation and glacial erosion}

The final phase of landscape evolution in western Lofoten, following Cenozoic uplift and rejuvenation, was exhumation of the Lofoten Ridge as a horst, still comprising its gently dipping Mesozoic rifted basement surface, rotated fault blocks, half-graben sedimentary basins, and bounding steep normal faults (Fig. 12A, B). During the exhumation steep scarps and lowrelief surfaces remained, and erosion removed the sedimentary cover, likely during the Late Cenozoic (last $20 \mathrm{Ma}$ ). Final removal of these sediments (except for rare small pockets in down-dropped hangingwall blocks, e.g. in Sortlandsundet) occurred during the Quaternary Period (last 2.6 Ma) when extended periods of local, cirque- and valley glacier erosion alternated with briefer periods of ice-sheet erosion, when glaciers periodically reached the shelf edge and inundated all landscape surfaces, except the highest summits (Ottesen et al., 2005a; Trulssen, 2008). Glacial erosion selectively followed valleys and tectonic zones of weakness (cf. Corner, 2005b; Osmundsen et al., 2010), causing deep incision in high areas hosting cirque glaciers, while only slightly modifying remnants of the relict, asymmetric landscape in broader, intermediate areas during periods of more extensive glaciations. One reason why glacial erosion did not fully remove relict surfaces is that glacial erosion in the Lofoten islands was of limited or local character and mostly occurred perpendicular to the average dip direction of low-relief surfaces (Rokoengen \& Sættem, 1983; Nordgulen et al., 2006). In particular, a major ice stream in Vestfjorden during the maximum glaciation prevented large ice masses from reaching the mountainous areas of Lofoten, which supported only local ice domes (Ottesen et al., 2005a, b; Fløistad et al., 2009; Laberg et al., 2009; Vorren et al., 2015).

Alternative interpretations of the low-relief palaeosurfaces are possible: One is that they reflect the elevated 'old' land surface, termed the palaeic surface (Reusch, 1901; Gjessing, 1967; Riis, 1992, 1996; Riis \& Fjeldskaard, 1992; Lidmar-Bergström et al., 2000, 2007), which was uplifted in pulses to different altitudes in the Neogene followed by fluvial incision (Japsen \& Chalmers, 2000; Bonow et al., 2007; Corner, 2005b; Lidmar-Bergström et al., 2007). A second alternative advocates a Quaternary 'glacial buzzsaw' mechanism (Nielsen et al., 2009, 2010; Steer et al., 2012), where the geomorphic surfaces were carved into an ancient topography that had been steadily eroded and isostatically uplifted.

Our work, however, rules out both of these hypotheses for the tilted palaeosurfaces in Lofoten, from the convincing relationship with the offshore tilted basement surfaces and rift-margin related tectonic features (see Fig. 14). The influence of glacial erosion on the landscape appears to be locally distinct and cannot explain the origin of the asymmetric landscape features. In the westernmost islands of Lofoten, remnants of a nearhorizontal surface are preserved at high altitude c. 800 m.a.s.l. (visible in distance in Fig. 2B). This surface is incised by glacial troughs and cirques but also cuts the tilted palaeosurfaces (Trulssen, 2008), suggesting that it is part of the palaeic surface as commonly understood, and that the coastal landscape of northern Norway contains palaeosurfaces of diverse age and origin (e.g., Gabrielsen et al., 2010).

The strandflat in the Lofoten area, however, is in our view a much younger feature than the uplifted Mesozoic surface remnants (see Figs. 2B \& 12C) and the presumed palaeic surface there, and thus, we cannot contribute to resolving how and when the strandflat evolved compared with the relict faults and fracture systems, at least not those limiting the Leknes half-graben.

\section{Tectonic evolution and landscape development}

Based on the data presented and discussed above, the Leknes half-graben onshore the Lofoten Ridge on Vestvågøya is considered to be a preserved relic of a fault-controlled Mesozoic landscape. It shows inherited attitudes of a Mesozoic basement surface gently tilted and bounded by steep normal faults, producing asymmetric rotated faults blocks and half-grabens within basement rocks that were exhumed in the Cenozoic. In this perspective, the onshore asymmetric landscapes and half-graben geometry of basement rocks on Vestvågøya are fully part of the Mesozoic rift-margin architecture (see Fig. 14).

After extensional collapse of the Caledonides in the Devonian (Andersen et al., 1994) and formation of the Lofoten Ridge as a metamorphic core complex in the Permian (Klein \& Steltenpohl, 1999; Steltenpohl et al., 2011), the margin was subjected to long-term Mesozoic-Cenozoic rifting (Blystad et al., 1995; Brekke, 2000; Tsikalas et al., 2005, 2008). Erosion and uplift in the Late Triassic to Early Jurassic generated a regional peneplained basement surface that was faulted and tilted during the main hyperextended rift phase of the Lofoten-Vesterålen margin (Tsikalas et al., 2001, 2005; Osmundsen et al., 2002; Bergh et al., 2007; Hansen et al., 2012; Peron-Pinvidic et al., 2013). In the Late Jurassic to Early/Mid Cretaceous, basin-boundary faults like the ELBF and WLBF (Fig. 14) formed along the margin, and synrift sediments were deposited on the tilted erosional surface in grabens and half-grabens (e.g., Vestfjorden, Ribban and Træna basins) (Bergh et al., 2007; Hansen et al., 2012). Our data suggest that the Leknes half-graben and bounding brittle faults formed during the TriassicJurassic and Late Jurassic to Early/Mid Cretaceous (cf. Bergh et al., 2007) and down-dropped the Caledonian Leknes Group. 

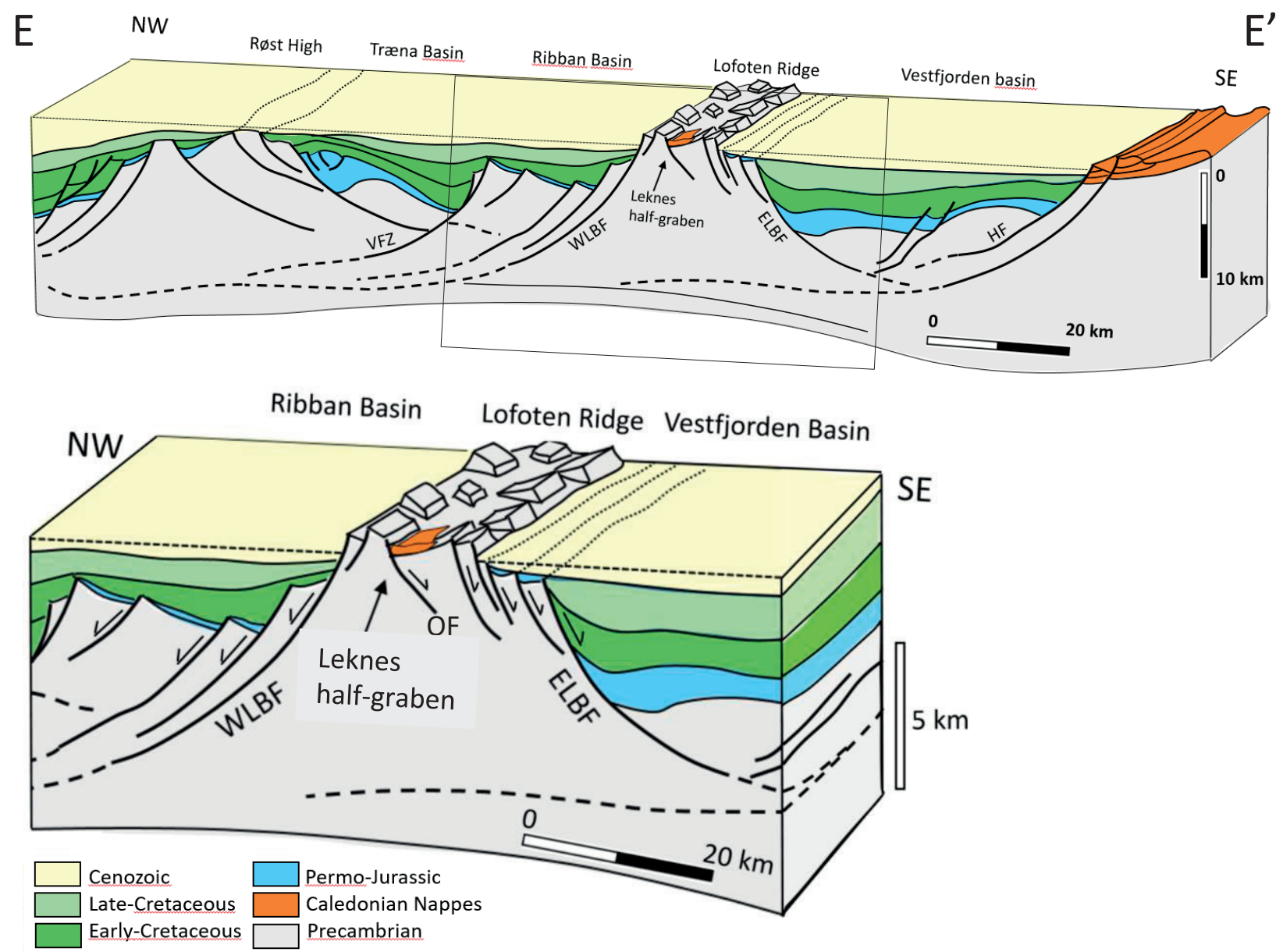

Figure 14. Sketch interpretation of a composite offshore seismic section parallel to line E-E' in Fig. 1, from the Røst High to mainland Nordland (Statoil lines L086R90-04 and L087R00-08), after Bergh et al. (2007), combined with a smaller, interpreted, onshore section across Vestvågøya. The enlarged part of the Lofoten Ridge (below) shows the interpreted onshore structures and asymmetric landscapes of the Leknes half-graben on Vestvågøya, and its relationship to offshore Mesozoic rift-margin structures.

During the Cenozoic, the Lofoten Ridge portion of the Mesozoic rifted margin was tectonically uplifted and gradually exhumed, preserving the rift-margin architecture (Osmundsen et al., 2010; Schermer et al., 2016) and creating asymmetric landscapes comprised of steep scarps and gently dipping low-relief surfaces. Mesozoic normal faults were partly reactivated, and footwalls possibly uplifted (Redfield et al., 2005; Hendriks et al., 2010).

During the Quaternary, glacial erosion modified the exhumed asymmetric landscape, further incising valleys, eroding peaks and ridges and locally producing deep cirques (Trulssen, 2008; Ottesen et al., 2005a), but leaving intact remnants of the tilted basement surfaces. This palaeosurface is still preserved, and the sedimentary cover mostly removed, except locally on Andøya and in fjords like Sortlandsundet. Glacial features such as cirques and U-shaped valleys are distinct in some areas, but glacial erosion has not removed or obscured the original Mesozoic palaeosurfaces inherited from the basement-cover contact.

\section{Conclusions}

(1) Asymmetric landscapes in Precambrian basement rocks at Leknes on Vestvågøya display a rhombicshaped geometry of valleys and scarps in map view, and an opposed, rotated half-graben geometry in cross-section. Steep $\left(>30^{\circ}\right)$ NE- and SW-dipping coast-parallel escarpments coincide with major brittle faults and high-density fracture zones, while gently inward dipping $\left(<30^{\circ}\right)$ smooth slopes and planar low-relief surfaces connecting summit peaks terminate against these steep faults. The asymmetric half-graben geometry is confirmed by aspect/ azimuth and surface relief data, and by a preserved, down-faulted erosional remnant of a Caledonian thrust nappe (Leknes Group) in its centre.

(2) Comparison of the onshore landscape at Vestvågøya with offshore shelf and rift-margin architectures shows that the Lofoten basement horst is bordered by opposing master normal faults (detachments) 
bounding major basins (Vestfjorden, Træna, Ribban) underlain by a basement-cover surface of Early Jurassic through Cretaceous age. This surface is gently tilted against steeper normal faults that delimit rotated fault blocks. The resulting half-grabens are filled by synrift Permo-Jurassic and Late Jurassic to Early/Mid Cretaceous sedimentary strata. Similar basins are observed on the horst interior in offshore seismic data south of the Lofoten islands, on the shallow shelf surrounding Vestvågøya, in the fjords of Vesterålen, and on Andøya.

(3) The gently dipping palaeosurfaces in basement rocks of the Leknes half-graben mimics the tilted Mesozoic basement-cover surface and rotated fault blocks that formed during the main rift phase in the Late Jurassic to Early Cretaceous on the LofotenVesterålen margin.

(4) In the Cenozoic, postrift uplift of the margin, aided by reactivation of normal faults, caused exhumation and erosion of most of the sedimentary cover. Internal asymmetric landscapes such as the Leknes half-graben, interpreted as a rotated fault block with steep scarps and tilted low-relief basement surfaces, remained as inherited features from the rift-margin architecture.

(5) During the Quaternary Period, the Lofoten Ridge was exhumed as a horst, and its inherited Mesozoic rift-margin features were incised locally by cirque erosion and elsewhere modified by limited glacial erosion during brief periods of more extensive glaciation, when ice stream development in Vestfjorden prevented build-up of large ice masses over Lofoten.

(6) Our work cannot verify other hypotheses discussed in the literature to explain Norwegian landscapes; firstly, that the tilted palaeosurfaces are part of the regional palaeic surface as identified throughout Norway; and secondly, that palaeosurfaces may form by the so-called glacial buzzsaw mechanism.

Acknowledgements. This work was funded by grants from UiT-The Arctic University of Norway and Statoil ASA, Harstad, and is part of an ongoing project studying onshore-offshore relationships of the SW Barents Sea margin (ARCEx-UiT). Statoil also funded rental costs for an aeroplane allowing us to take aerial photographs of the asymmetric landscapes around Leknes. We thank the reviewers, Elizabeth Schermer and Per Terje Osmundsen, for their constructive comments and suggestions that helped to improve the final manuscript.

\section{References}

Aleksandrowski, P. 1985: Graphical determination of principal stress directions from slickenside lineation populations: an attempt to modify Arthaud's method. Journal of Structural Geology 7, 73-82. https://doi.org/10.1016/0191-8141(85)90116-6.

Andersen T.B., Osmundsen, P.T. \& Jolivet, L. 1994: Deep-crustal fabrics and a model for the extensional collapse of the Southwest Norwegian Caledonides. Journal of Structural Geology 16, 11911203. https://doi.org/10.1016/0191-8141(94)90063-9.

Bergh, S.G., Eig, K., Kløvjan, O.S., Henningsen, T., Olesen, O. \& Hansen, J.A. 2007: The Lofoten-Vesterålen continental margin: a multiphase Mesozoic-Palaeogene rifted shelf as shown by offshore-onshore brittle fault-fracture analysis. Norwegian Journal of Geology 87, 29-58.

Bergh, S.G., Corfu, F. \& Corner, G.D. 2008: Proterozoic igneous and metamorphic rocks: a template for Mesozoic-Cenozoic brittle faulting and tectonic inherited landscapes in Lofoten-Vesterålen, North Norway. 33 IGC Excursion Guidebook No. 38, IGC The Nordic Countries.

Blystad, P., Brekke, H., Færseth, R.B, Larsen, B.T., Skogseid, J. \& Tørudbakken, B. 1995: Structural elements of the Norwegian continental shelf. Part II: The Norwegian Sea Region. Norwegian Petroleum Directorate, Bulletin 8, 1-45.

Bonow, J., Japsen, P., Lidmar-Bergstrom, K., Chalmers, J.A. \& Pedersen, A.K. 2006: Cenozoic uplift of Nuussuaq and Disko, West Greenland-elevated erosion surfaces as uplift markers of a passive margin. Geomorphology 80, 325-337. https://doi.org/10.1016/j.geomorph.2006.03.006.

Bonow, J.M., Lidmar-Bergstrom, K., Japsen, P., Chalmers, J.A. \& Green, P.F. 2007: Elevated erosion surfaces in central West Greenland and southern Norway: their significance in integrated studies of passive margin development. Norsk Geologisk Tidsskrift 87, 197-206.

Brekke, H. 2000: The tectonic evolution of the Norwegian Sea continental margin, with emphasis on the Voring and More basins. In Nøttvedt, A. (ed.): Dynamics of the Norwegian Margin, Geological Society of London, Special Publications 167, pp. 327378. https://doi.org/10.1144/GSL.SP.2000.167.01.13.

Brekke, H., Sjulstad, H.I., Magnus, C. \& Williams, R.W. 2001: Sedimentary environments offshore Norway - an overview. In Martinsen, O.J. \& Dreyer, T. (eds.): Sedimentary environments offshore Norway- Palaeozoic to Recent, Norwegian Petroleum Society Special Publication 10, pp. 7-37. https://doi.org/10.1016/S0928-8937(01)80006-0.

Burke, K. \& Gunnell, Y. 2008: The African Erosion Surface: A Continental-Scale Synthesis of Geomorphology, Tectonics and Environmental Change over the Past 180 Million Years. Geological Society of America Memoirs 201. https://doi.org/10.1130/2008.1201.

Bøe, R., Fossen, H. \& Smelror, M. 2010: Mesozoic sediments and structures onshore Norway and in the coastal zone. Norges Geologiske Undersøkelse Bulletin 450, 15-32.

Corfu, F. 2004: U-Pb Age, Setting and Tectonic Significance of the Anorthosite-Mangerite- Charnockite-Granite Suite, LofotenVesterålen, Norway. Journal of Petrology 45, 1799-1819. https://doi.org/10.1093/petrology/egh034.

Corfu, F. 2007: Multistage metamorphic evolution and nature of the amphibolite-granulite facies transition in Lofoten-Vesterålen, Norway, revealed by $\mathrm{U}-\mathrm{Pb}$ in accessory minerals. Chemical Geology 241, 108-128. https://doi.org/10.1016/j.chemgeo.2007.01.028.

Corner, G.D. 2005a: Atlantic coast and fjords. In Seppälä, M. (ed.): The Physical Geography of Fennoscandia. Oxford Regional Environments Series, pp. 203-228.

Corner, G.D. 2005b: Scandes Mountains. In Seppälä, M. (ed.): The Physical Geography of Fennoscandia. Oxford Regional Environments Series, pp. 229-254. 
Dalland, A. 1981: Mesozoic sedimentary succession at Andøya, Northern Norway, and relation to structural development of the North Atlantic area. Canadian Society of Petroleum Geologist Memoir 7, 563-584.

Davids, C., Wemmer, K., Zwingmann, H., Kohlmann, F., Jacobs, J. \& Bergh, S.G. 2013: K-Ar illite and apatite fission track constraints on brittle faulting and the evolution of the northern Norwegian passive margin. Tectonophysics 608, 196-211. https://doi.org/10.1016/j.tecto.2013.09.035.

Davidsen, B., Somaruga, A. \& Bøe, R. 2001: Sedimentation, tectonics and uplift in Vesterålen; Phase-1: Localizing near-shore faults and Mesozoic sediment basins. NGU Report 2001.111,10pp.

Doré, A.G. 1991: The structural foundation and evolution of Mesozoic seaways between Europe and the Arctic. Palaeogeography, Palaeoclimatology, Palaeoecology 87, 441-492. https://doi.org/10.1016/0031-0182(91)90144-G.

Doré, A.G., Lundin, E.R., Fichler, C. \& Olesen, O. 1997: Patterns of basement structure and reactivation along the NE Atlantic margin. Journal of the Geological Society of London 154, 85-92. https://doi.org/10.1144/gsigs.154.1.0085.

Doré, A.G., Lundin, E.R., Jensen, L.N., Birkeland, Ø., Eliassen, P.E. \& Fichler, C. 1999: Principal tectonic events in the evolution of the northwest European Atlantic margin. In Fleet, A.J. \& Boldy, S.A.R. (eds.): Petroleum Geology of Northwest Europe, Proceedings of the Fifth Conference, London Geological Society, pp. 7-37. https://doi.org/10.1144/0050041.

Eig, K. 2008: Onshore and offshore tectonic evolution of the Lofoten passive margin, North Norway. $\mathrm{PhD}$ thesis, University of Tromsø, $256 \mathrm{pp}$.

Eig, K. \& Bergh, S.G. 2011: Late Cretaceous-Cenozoic fracturing in Lofoten, North Norway: Tectonic significance, fracture mechanisms and controlling factors. Tectonophysics 499, 190-205. https://doi.org/10.1016/j.tecto.2010.12.002.

Etzelmüller, B., Romstad, B. \& Fjellanger, J. 2007: Automatic regional classification of topography in Norway. Norwegian Journal of Geology 87, 167-180.

Faleide, J.I., Tsikalas, F., Breivik, A.J., Mjelde, R., Ritzmann, O., Engen, Ø. \& Eldholm, O. 2008: Structure and evolution of the continental margin off Norway and the Barents Sea. Episodes 31, 82-91.

Fløistad, K.R., Laberg, J.S. \& Vorren, T.O. 2009: Morphology of Younger Dryas subglasial and iceproximal submarine landforms, inner Vestfjorden, northern Norwa. Boreas 38, 610-619. https://doi.org/10.1111/j.1502-3885.2008.00080.x.

Forthun, T. 2014: Onshore-offshore correlation in the Andfjorden area and the structural controls on the opening and evolution of the Mesozoic sedimentary basins on Andøya and Andfjorden, northern Norway. MSc thesis, The Arctic University of Norway, $114 \mathrm{pp}$.

Fredin, O., Viola, G., Zwingmann, H., Sørlie, R., Brőnner, M., Lie, J.E., Grandal, E.M., Müller, A., Margreth, A., Vogt, C. \& Knies, J. 2017: The inheritance of a Mesozoic landscape in western Scandinavia. Nature Communications 8. https://doi.org/10.1038/ncomms14879.

Fürsich, F. \& Thomsen, E. 2005: Jurassic biota and biofacies in erratics from the Sortland area, Vesterålen, northern Norway. Geological Survey of Norway Bulletin 443, 37-53

Færseth, R.B. 2012: Structural development of the continental shelf offshore Lofoten- Vesterålen, northern Norway. Norwegian Journal of Geology 92, 19-40.

Gabrielsen, R.H., Braathen, A., Dehls, J. \& Roberts, D. 2002: Tectonic lineaments of Norway. Norwegian Journal of Geology 82, 153-174.

Gabrielsen, R.H., Faleide, J.I., Pascal, C., Braathen, A., Nystuen, J.P., Etzelmuller, B. \& O'Donnell, S. 2010: Latest Caledonian to Present tectonomorphological development of southern Norway. Marine and Petroleum Geology 27, 709-723.

https://doi.org/10.1016/j.marpetgeo.2009.06.004.

Gjessing, J. 1967: Norway's paleic surface. Norwegian Journal of Geology 21, 69-132. https://doi.org/10.1080/00291956708621854.
Griffin, W.L., Taylor, P.N., Hakkinen, J.W., Heier, K.S., Iden, I.K., Krogh, E.J., Malm, O., Olsen, K.I., Ormaasen, D.E. \& Tveten, E. 1978: Archaean and Proterozoic crustal evolution in Lofoten-Vesterålen, N. Norway. Journal of the Geological Society of London 135, 629647. https://doi.org/10.1144/gsjgs.135.6.0629.

Hansen, J.A. 2009: Onshore-offshore tectonic relations on the Lofoten and Vesterålen Margin, North Norway: Mesozoic to Early Cenozoic structural evolution and morphological implications. $\mathrm{PhD}$ thesis, University of Tromsø, $229 \mathrm{pp}$.

Hansen, J.A., Bergh, S.G., Henningsen, T. \& Davids, C. 2011: Brittle fault zones in North Norway: Onshore-offshore link and regional implications. NGF Abstracts and Proceedings of the Geological Society of Norway No.1, pp. 37.

Hansen, J.A., Bergh, S.G. \& Henningsen, T. 2012: Mesozoic rifting and basin evolution on the Lofoten and Vesterålen Margin, North Norway; time constraints and regional implications. Norwegian Journal of Geology 91, 203-228.

Haraldsvik, K.L. 2015: Analyse av mesozoiske forkastninger og asymmetriske landskap $i$ et profil over Lofotryggen ved Leknes, Vestvågøy; Implikasjoner for dannelsen av roterte forkastningsblokker, riftrelaterte bassenger og nedforkastningen av Leknesgruppen. MSc thesis, University of Tromsø, 108 pp.

Hendriks, B.W.H. 2003: Cooling and denudation of the Norwegian and Barents Sea margins, Northern Scandinavia constrained by apatite fission track and $\mathrm{U}-\mathrm{Th} / \mathrm{He}$ thermochronology. $\mathrm{PhD}$ thesis, Vrije Universiteit Amsterdam, 177 pp

Hendriks, B.W.H., Andriessen, P.A.M., Huigen, Y., Leighton, C., Redfield, T., Murrell, G., Gallagher, K. \& Nielsen, S.B. 2007: A fission track data compilation for Fennoscandia. Norwegian Journal of Geology 87, 143-156.

Hendriks, B.W.H., Osmundsen, P.T. \& Redfield, T.F. 2010: Normal faulting and block tilting in Lofoten and Vesterålen constrained by Apatite Fission Track data. Tectonophysics 485, 154-163. https://doi.org/10.1016/j.tecto.2009.12.011.

Henstra, G.A. \& Rotevatn, A. 2014: Nature of Palaeozoic extension in Lofoten, north Norwegian Continental Shelf: insights from 3-D seismic analysis of a Cordilleran- style metamorphic core complex. Terra Nova 26, 247-252. https://doi.org/10.1111/ter.12098.

Henstra, G.A., Gawthorpe, R.L., Helland-Hansen,W., Ravnås, R. \& Rotevatn, A. 2016: Depositional systems in multiphase rifts: seismic case study from the Lofoten margin, Norway. Basin Research 29, $1-23$.

Indrevær, K., Bergh, S.G., Koehl, J.B., Hansen, J.A., Schermer, E.R. \& Ingebrigtsen, A. 2013: Post-Caledonian brittle fault zones on the hyperextended SW Barents Sea margin: New insights into onshore and offshore margin architecture. Norwegian Journal of Geology 93, 167-188.

Japsen, P. \& Chalmers, J.A. 2000: Neogene uplift and tectonics around the North Atlantic: overview. Global and Planetary Change 24, 65-173. https://doi.org/10.1016/S0921-8181(00)00006-0.

Johannesen, E.P. \& Nøttvedt, A. 2008: Norway encircled in coastal plains and deltas. In Ramberg, I., Bryhni, I., Nøttvedt, A. \& Rangnes, K. (eds): The Making of a Land: Geology of Norway. The Geological Society of Norway, pp. 356-383.

Klein, A.C. 1997: Geology of the Leknes group and underlying basement in west-central Vestvågøy, north Norway. PhD thesis, Auburn University, $171 \mathrm{pp}$.

Klein, A.C. \& Steltenpohl, M.G. 1999: Basement-cover relations and late- to post- Caledonian extension in the Leknes group, westcentral Vestvågøy, Lofoten, north Norway. Norwegian Journal of Geology 79, 19-31. https://doi.org/10.1080/002919699433889.

Klein, A.C., Steltenpohl, M.G., Hames, W.E. \& Andresen, A. 1999: Ductile and brittle extension in the southern Lofoten ortherngo, north Norway: Implications for differences in tectonic style along an ancient collisional margin. American Journal of Science 299, 69-89. https://doi.org/10.2475/ajs.299.1.69. 
Laberg, J.S., Eilertsen, R.S. \& Vorren, T.O. 2009: The paleo-ice stream in Vestfjorden, north Norway, over the last 35 k.y.: Glacial erosion and sediment yield. Geological society of America Bulletin 121, 434-447. https://doi.org/10.1130/B26277.1.

Lidmar-Bergström, K. 1999: Uplift histories revealed by landforms of the Scandinavian domes. In Smith, B.J., Whalley, W.B. \& Warke, P.A. (eds): Uplift, Erosion and Stability: Perspectives on Long-term Landscape Development. Geological Society, London Special Publications 162, pp. 85-91.

https://doi.org/10.1144/GSL.SP.1999.162.01.07.

Lidmar-Bergström, K., Ollier, C.D. \& Sulebak, J.R. 2000: Landforms and uplift history of southern Norway. Global and Planetary Change 24, 211-231. https://doi.org/10.1016/S0921-8181(00)00009-6.

Lidmar-Bergström, K., Naslund, J., Ebert, K., Neubeck, T. \& Bonow, J.M. 2007: Cenozoic landscape development on the passive margin of orthern Scandinavia. Norwegian Journal of Geology 87, 181-196.

Lundekvam, P. 2015: Land sokkel korrelasjon av sprø mesozoiske og paleozoiske forkastninger $i$ et profil over Vestfjordbassenget, Vestvågøya og Ribbebassenget. MSc thesis, University of Tromsø, 92 pp.

Løseth, H. \& Tveten, E: 1996. Post-Caledonan structural evolution of the Lofoten and Vesterålen offshore and onshore areas. Norwegian Journal of Geology 76, 215-230.

Mosar, J., Eide, E.A., Osmundsen, P.T., Sommaruga, A. \& Torsvik, T.H. 2002: Greenland- Norway separation: A geodynamic model for the North Atlantic. Norwegian Journal of Geology, 82, 281-298.

Møller, J.J. \& Sollid, J.L. 1973: Geomorfologisk kart over LofotenVesterålen (with English summary). Norwegian Journal of Geology 27, 195-205. https://doi.org/10.1080/00291957308551957.

Nielsen, S.B., Gallagher, K., Leighton, C., Balling, N., Svenningsen, L. Jacobsen, B.H., Thomsen, E., Nielsen, O.B., Heilmann-Clausen, C., Egholm, D.L., Summerfield, M.A., Clausen, O.R, Piotrowski, J.A., Thorsen, M.R., Huuse, M., Abrahamsen, N., King, C. \& Lykke-Andersen, H. 2009: The evolution of western Scandinavian topography: a review of neogene uplift versus the ICE (isostasyclimate-erosion) hypothesis. Journal of Geodynamics 47, 72-95. https://doi.org/10.1016/j.jog.2008.09.001.

Nielsen, S.B., Clausen, O.R., Pedersen, V.K., Leseman, J.E., Goledowski, B., Huuse, M., Gallagher, K. \& Summerfield, M.A., 2010: Discussion of Gabrielsen et al. (2010): Latest Caledonian to Present tectonomorphological development of southern Norway. Marine and Petroleum Geology 27, 1285-1289.

https://doi.org/10.1016/j.marpetgeo.2010.02.004.

Nordgulen, Ø., Bargel, T.H., Longva, O., Olesen, O. \& Ottesen, D. 2006: A preliminary study of Lofoten as a potential World Heritage Site based on natural criteria. NGU Report 2005.086, 27 pp.

Olesen, O., Torsvik, T.H., Tveten, E., Zwaan, K.B., Løseth, H. \& Henningsen, T. 1997: Basement structure of the continental margin in the Lofoten-Lophavet area, northern Norway: constraints from potential field data, on-land structural mapping and palaeomagnetic data. Norwegian Journal of Geology 77, 15-30.

Olesen, O., Pascal-Kierulf, H., Brönner, M., Dalsegg, E., Fredin, O. \& Solbakk, T. 2013: Deep weathering, neotectonics and strandflat formation in Nordland, northern Norway. Norwegian Journal of Geology 93, 189-213.

Osmundsen, P.T. \& Redfield, T.F. 2011: Crustal taper and topography at passive continental margins. Terra Nova 23, 349-361. https://doi.org/10.1111/j.1365-3121.2011.01014.x.

Osmundsen, P.T., Sommaruga, A., Skilbrei, J.R. \& Olesen, O. 2002: Deep structure of the Mid Norway rifted margin. Norwegian Journal of Geology 82, 205-224.

Osmundsen, P.T., Henderson, I., Lauknes, T.R., Larsen, Y., Redfield, T.F. \& Dehls, J. 2009: Active normal fault control on landscape and rock-slope failure in Northern Norway. Geology 37, 135-138. https://doi.org/10.1130/G25208A.1.
Osmundsen, P.T., Redfield, T.F., Hendriks, B.H.W., Bergh, S., Hansen, J.A., Henderson, I.H.C., Dehls, J., Lauknes, T.R., Larsen, Y., Anda, E. \& Davidsen, B. 2010: Fault- controlled alpine topography in Norway. Journal of the Geological Society London 167, 83-98. https://doi.org/10.1144/0016-76492009-019.

Ottesen, D., Dowdeswell, J.A. \& Rise, L. 2005a: Submarine landforms and the reconstruction of fast-flowing ice streams within a large Quaternary ice sheet: The 2500-km-long Norwegian-Svalbard margin $\left(57^{\circ}-80^{\circ} \mathrm{N}\right)$. Geological Society of America Bulletin 117, 1033-1050. https://doi.org/10.1130/B25577.1.

Ottesen, D., Rise, L., Knies, J., Olsen, L. \& Henriksen, S. 2005b: The Vestfjorden- Trænadjupet palaeo-ice stream drainage system, midNorwegian continental shelf Marine Geology 218, 175-189. https://doi.org/10.1016/j.margeo.2005.03.001.

Péron-Pinvidic, G., Manatschal, G. \& Osmundsen, P.T. 2013: Structural comparison of archetypal Atlantic rifted margins: A review of observations and concepts. Marine and Petroleum Geology 43, 21-47. https://doi.org/10.1016/j.marpetgeo.2013.02.002.

Redfield, T.F. \& Osmundsen, P.T. 2013: The long-term topographic response of a continent adjacent to a hyperextended margin; a case study from Scandinavia. Geological Society of America Bulletin 125, 184-200. https://doi.org/10.1130/B30691.1.

Redfield, T.F., Osmundsen, P.T. \& Hendriks, B.W.H. 2005: The role of fault reactivation and growth in the uplift of western Fennoscandia. Journal of the Geological Society London 162, 1013-1030. https://doi.org/10.1144/0016-764904-149.

Reusch, H. 1901: Nogle bidrag til forstaaelsen af hvorledes Norges dale og fjelde er blevne til. Geological Survey of Norway Publication 32, 124-263.

Riis, F. 1992: Dating and measuring of erosion, uplift and subsidence in Norway and the Norwegian shelf in glacial periods. Norwegian Journal of Geology 72, 325-331.

Riis, F. 1996: Quantification of Cenozoic vertical movements of Scandinavia by correlation of morphological surfaces with offshore data. Global and Planetary Change 12,331- 357. https://doi.org/10.1016/0921-8181(95)00027-5.

Riis, F. \& Fjeldskaar, W. 1992: On the magnitude of the Late Tertiary and Quaternary erosion and its significance for the uplift of Scandinavia and the Barents Sea. In Larsen, R.M., Brekke, H., Larsen, B.T. \& Talleraas, E. (eds): Structural and Tectonic Modelling and its Application to Petroleum Geology, Norwegian Petroleum Society Special Publication 1, pp. 163-185. https://doi.org/10.1016/B978-0-444-88607-1.50016-4.

Rokoengen, K. \& Sættem, J. 1983: Shallow bedrock geology and Quaternary thickness off Northern Helgeland, Vestfjorden and Lofoten. Continental Shelf Institute Report P- 155/2/83, 44 pp.

Schermer, E.R., Redfield, T.F., Indrevær, K. \& Bergh, S.G. 2016: Geomorphology and topography of relict surfaces: the influence of inherited crustal structure in the northern Scandinavian Mountains. Journal of the Geological Society of London 174, 93-109. https://doi.org/10.1144/jgs2016-034.

Smelror, M., Mørk, A., Mørk, M.B.E., Weiss, H.M. \& Løseth, H. 2001: Middle Jurassic- lower Cretaceous transgressive-regressive sequences ond facies distribution off northern Nordland and Troms, Norway. Norwegian Petroleum Society Special Publications 10,211-232. https://doi.org/10.1016/S0928-8937(01)80015-1.

Smelror, M., Dehls, J., Ebbing, J., Larsen, E., Lundin, E.R., Nordgulen, Ø., Osmundsen, P.T., Olesen., O., Ottesen, D., Pascal, C., Redfield, T. \& Rise, L. 2007: Towards a 4D topographic view of the Norwegian Sea margin. Global and Planetary Change 58, 382-410. https://doi.org/10.1016/j.gloplacha.2006.12.005.

Steer, P., Huismans, R.S., Valla, P.G., Gac, S. \& Herman, F. 2012: Bimodal Plio-Quaternary glacial erosion of fjords and low-relief surfaces in Scandinavia. Nature Geoscience Letters 5, 635-639. https://doi.org/10.1038/ngeo1549. 
Steltenpohl, M.G., Hames, W.E. \& Andresen, A. 2004: The Silurian to Permian history of a metamorphic core complex in Lofoten, northern Scandinavian Caledonides. Tectonics 23, 1-23.

https://doi.org/10.1029/2003TC001522.

Steltenpohl, M.G., Moecher, D., Andresen, A., Ball, J., Mager, S. \& Hames, W.E. 2011: The Eidsfjord Shear Zone, Lofoten-Vesterålen, North Norway: An early Devonian, paleoseismigenic low-angle normal fault. Journal of Structural Geology 33, 1023- 1043. https://doi.org/10.1016/j.jsg.2011.01.017.

Trulssen, M.F. 2008: Sammenhengen mellom landskap og tektonikk på Moskenesøya og Flakstadøya, Lofoten. MSc thesis, University of Tromsø, $117 \mathrm{pp}$.

Tsikalas, F., Faleide, J.I. \& Eldholm, O. 2001: Lateral variations in tectono-magmatic style along the Lofoten-Vesterålen volcanic margin off Norway. Marine and Petroleum Geology 18, 807-832. https://doi.org/10.1016/S0264-8172(01)00030-7.

Tsikalas, F., Eldholm, O. \& Faleide, J.I. 2005: Crustal structure of the Lofoten-Vesterålen continental margin off Norway. Tectonophysics 404, 151-174. https://doi.org/10.1016/j.tecto.2005.04.002.

Tsikalas, F., Faleide, J.I. \& Kusznir, N.J. 2008: Along-strike variations in rifted margin crustal architecture and lithosphere thinning between northern Vøring and Lofoten margin segments off midNorway. Tectonophysics $458,68-81$. https://doi.org/10.1016/j.tecto.2008.03.001.

Tull, J.F. 1977: Geology and structure of Vestvågøy, Lofoten, North Norway. Geological Survey of Norway 333, 1-59.

Tveten, E. 1978: Geologisk kart over Norge, bergrunnskart Svolvær, scale 1:250,000, Norges geologiske undersøkelse.

Vorren, T.O., Rydningen, T.A., Baeten, N.J., Laberg, J.S. 2015: Chronology and extent of the Lofoten-Vesterålen sector of the Scandinavian Ice Sheet from 26 to 16 cal. Ka BP. Boreas 10, 445458. https://doi.org/10.1111/bor.12118.

Weissel, J.K. \& Karner, G.D. 1989. Flexural uplift of rift flanks due to mechanical unloading of the lithosphere during extension. Journal of Geophysical Research, 94, 13919- 13950. https://doi.org/10.1029/JB094iB10p13919.

Wilson, R.W., McCaffrey, K.J.W., Holdsworth, R.E., Imber, J., Jones, R.R., Welbon, A.I.F. \& Roberts, D. 2006: Complex fault patterns, transtension and structural segmentation of the Lofoten Ridge, Norwegian margin: Using digital mapping to link onshore and offshore geology. Tectonic, 25.

https://doi.org/10.1029/2005TC001895. 